

\section{DISCLAIMER}

This report was prepared as an account of work sponsored by an agency of the United States Government. Neither the United States Government nor any agency Thereof, nor any of their employees, makes any warranty, express or implied, or assumes any legal liability or responsibility for the accuracy, completeness, or usefulness of any information, apparatus, product, or process disclosed, or represents that its use would not infringe privately owned rights. Reference herein to any specific commercial product, process, or service by trade name, trademark, manufacturer, or otherwise does not necessarily constitute or imply its endorsement, recommendation, or favoring by the United States Government or any agency thereof. The views and opinions of authors expressed herein do not necessarily state or reflect those of the United States Government or any agency thereof. 


\section{DISCLAIMER}

Portions of this document may be illegible in electronic image products. Images are produced from the best available original document. 
This work was supported by the US Agency for International Deoelopment.

An Affirmatioe Action/Equal Opportunity Employer

This report was prepared as an account of work sponsored by an egency of the

United States Government. Neither The Regents of the University of Califormia, the United States Government nor any agency thereof, nor any of their employees, makes any warranty, express or implied, or assumes any legal liability or responsibility for the accuracy, completeness, or usefulness of any information, apparatus, product, or process disclosed, or represents that its use would not infringe prioately owned rights. Reference herein to any specific commercial product, process, or service by trade name, trademark, manufacturer, or otherwise, does not necessarily constitute or imply its endorsement, recommendation, or frooring by The Regents of the University of Califormia, the United States Government, or any agency thereof. The views and opinions of authors expressed herein do not necessarily refiect those of The Regents of the Unioersity of California, the United States Gooernment, or any agency thereof. 


\section{Geothermal Demonstration:}

\section{Zunil Food Dehydration Facility}

Oscar Maldonado*

John Altseimer

Leon Cooper**

Andrés Caicedo ${ }^{* * *}$

Gary R. Thayer

* Consultecnia, Apartado Postal 537-1, Guatemala City, GUATEMALA.

${ }^{* *}$ Energy Associates International, 2300-B, Markham S.W., Albuquerque, NM 87105.

** INDE, Edificio La Torre, 7a Avenida 2-29, Zona 9,

Guatemala City, GUATEMALA.

\section{MASTER}

DISTRIBUTION OF THIS DOCUMENT IS UNLIMITED

DISTRIBUTION

ดS A 


\section{CONTENTS}

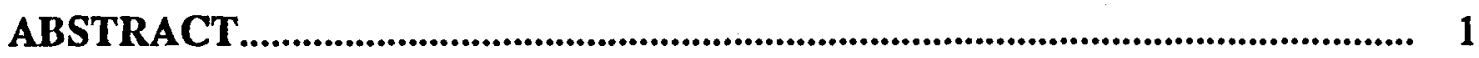

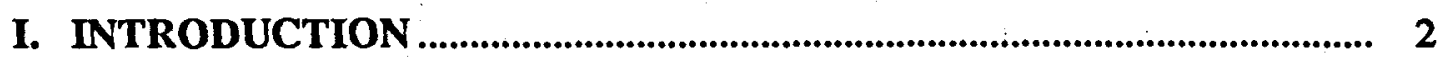

A. Purpose.......................................................................................................... 2

B. Reasons for Choosing Direct Heat Applications of Geothermal Energy... 2

C. Background ............................................................................................................. 3

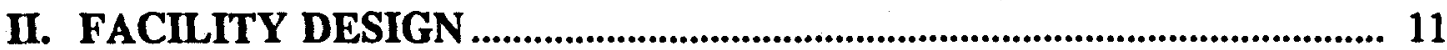

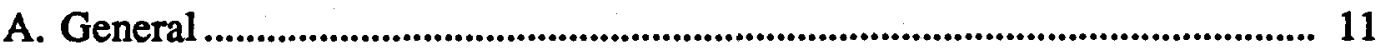

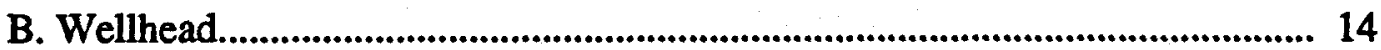

C. Wellhead and Heat Loop Interface .................................................................. 14

D. Hot Water Loop .......................................................................................................... 17

E. Dehydration Facility ................................................................................................... 20

F. Dehydration Tunnel......................................................................................... 20

G. Food Processing Area .......................................................................................... 22

H. Auxiliary Areas........................................................................................... 22

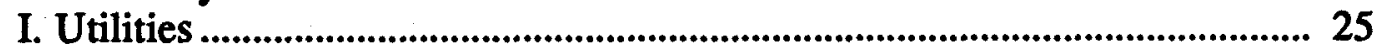

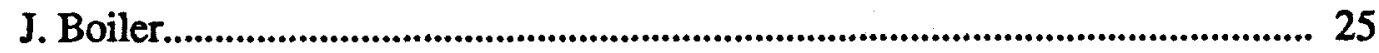

III. OPERATIONAL EXPERIENCE....................................................... 27

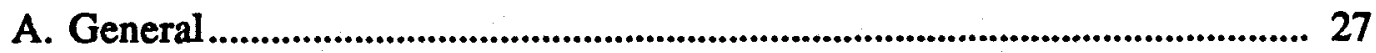

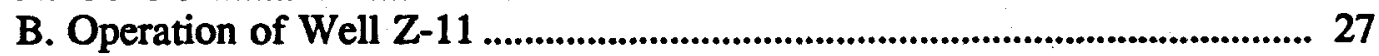

C. Operation of the Heat Loop............................................................................... 28

D. Operation of the Dehydration Tunnel ............................................................. 29

E. Operational Experience With the Instrumentation......................................... 35

F. Operational Experience With Other Portions of the Plant ............................ 35

IV. PRODUCT PROCESSING...................................................................... 37

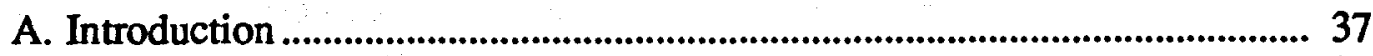

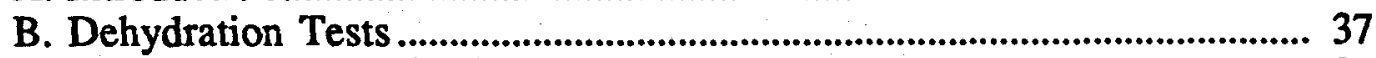

C. Results and Conclusions ................................................................................. 37

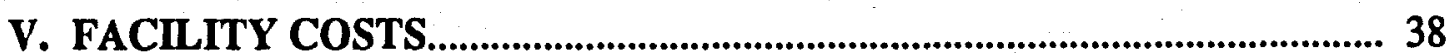

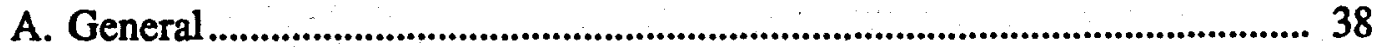

B. Faciity Cost Estimate...................................................................................... 38

C. Cost of Conventional Heat Supply (Boiler)..................................................... 40

D. Operating Costs........................................................................................... 41

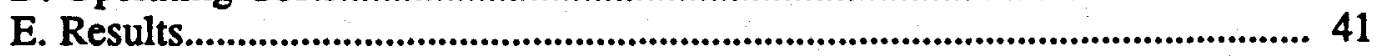

VI. SUMMARY AND RECOMMENDATIONS ............................................. 44

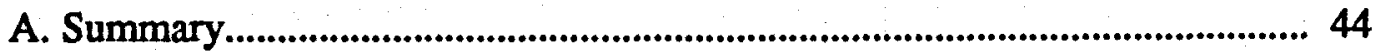

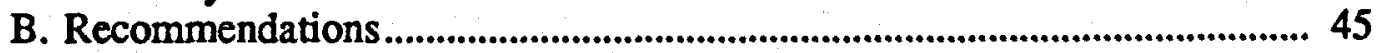

C. Other Industrial Applications of Geothermal Energy ..................................... 45

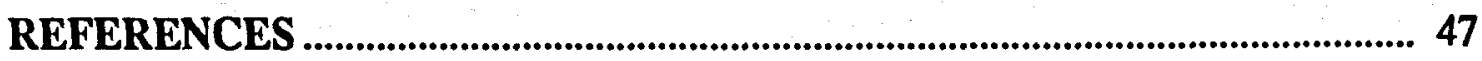

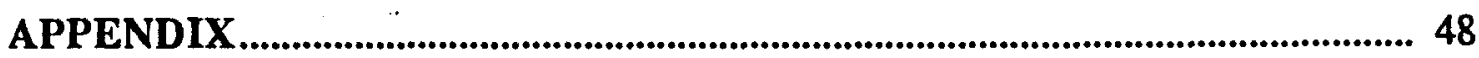




\title{
GEOTHERMAL DEMONSTRATION: ZUNIL FOOD DEHYDRATION FACILITY
}

\author{
by \\ Oscar Maldonado \\ John Altseimer \\ Leon Cooper \\ Andrés Caicedo \\ Gary R. Thayer
}

\begin{abstract}
A food dehydration facility was constructed near the town of Zunil, Guatemala, to demonstrate the use of geothermal energy for industrial applications. The facility was connected to Well Z-11, a slim-hole exploratory well that had been drilled early in the development of the Zunil Geothermal Well Field. Los Alamos National Laboratory was responsible for the design of the facility. Actual construction was done by INDE (Instituto Nacional de Electrificación), the national electric utility of Guatemala, and by workers under the supervision of Oscar Maldonado, the plant manager. The facility was completed in January 1989 but was unable to operate using geothermal energy until November 1989 because of ongoing testing in the rest of the Zunil Geothermal Field. Testing the facility using geothermal energy began in November and proceeded until operational responsibility for the facility was assumed by MOSCAMED in February 1990.
\end{abstract}

The facility, with some modifications to the design, was found to work quite satisfactorily. Tests using five different products were completed during the time geothermal energy was used in the plant. During the time the plant was not able to use geothermal energy, a temporary diesel-fueled boiler provided the energy to test dehydration on seven other crops available in the area.

The system demonstrates that geothermal heat can be used successfully for dehydrating food products. Many other industrial applications of geothermal energy could be considered for Zunil since a considerable amount of moderate-temperature heat will become available when the planned geothermal electrical facility is constructed there. 


\section{INTRODUCTION}

\section{A. Purpose}

The purpose of this project is to technically demonstrate an industrial or a direct heat application of geothermal energy. The application chosen for this technical demonstration was a subcommercial-size food dehydration facility located at the Zunil Geothermal Well Field. Steam energy for the facility was supplied by Well Z-11, a slim-hole exploratory well that had been drilled at the start of the work on the Zunil Geothermal Field.

Once the technical demonstration of the direct heat application was completed, the second goal of the project was to transfer the facility to a Guatemalan organization which could then use the facility to promote new food processing methods and develop new markets for the produce locally grown.

This report presents the design and operating parameters of the facility. It also presents the information on dehydration tests that were performed when the facility operated with geothermal steam from Well Z-11 and when it operated with a boiler while the well was shut down during testing at the Zunil Geothermal Field.

\section{B. Reasons for Choosing Direct Heat Applications of Geothermal Energy}

Geothermal energy exists widely in Central America. It is being used to produce electrical power in El Salvador and Nicaragua and plans for electrical generation from geothermal energy are under way in Costa Rica and Guatemala. Because this resource exists widely in Central America, it is logical to use it in solving some of the Central American energy problems.

Industrial or direct heat applications of geothermal energy typically require less stringent conditions, such as temperature and total energy requirements, than do electrical power plants. Industrial applications can use temperatures lower than steam used in electrical production and/or have a lower flow rate than that required for an electrical plant. Industrial applications can also use the large amounts of mediumgrade waste heat rejected from geothermal electrical plants. 
No direct heat applications of geothermal energy have been demonstrated in Central America. However, other countries are interested in direct heat applications. Using geothermal energy for direct heat applications is routine in the US and Iceland. Small demonstration projects have been carried out in Hawaii, and specific applications have been proposed in the US.1,2 A facility in Wendell, California, uses geothermal energy to run two $300-\mathrm{kWe}$ binary generators and then uses the waste heat to warm a greenhouse for producing specialty crops. ${ }^{3}$ Geothermal energy is also being used in Nevada to warm fish ponds for tropical fish production. ${ }^{4}$ One commercial plant, an onion dehydrating facility in Nevada operated by Gilroy Foods, Inc., gets most of its heat from geothermal energy.

\section{Background}

The direct heat demonstration was part of the Los Alamos National Laboratory Central American Energy and Resources Project funded by the US Agency for International Development. The purpose of the project was to assist Central American countries in developing their energy resources and to provide advice on energy matters and planning. The geothermal resources of Central America were of particular interest. A large part of the project was devoted to assisting Central American countries in defining their geothermal resources and, as part of this geothermal assistance, Los Alamos recommended that direct heat applications of geothermal energy be considered.

To support the above recommendation, Los Alamos did a study to examine the possible industrial applications of geothermal energy. 5 This study determined that the most appropriate areas for industrial applications of geothermal energy were an industrial park in the Amatitlán area and food processing facilities at the Zunil Geothermal Field. Since the Zunil Field was well along in its development, the demonstration project was installed there. The Zunil Field is located near the village of Zunil some $10 \mathrm{~km}$ south of Quezaltenango, the second largest city in Guatemala, along the highway between Quezaltenango and Retalhuleu (Fig. 1). The area around the Zunil Geothermal Field is the major produce farming area for Guatemala (Figs. 2 and 3). Farming cooperatives in the area are experimenting with growing and marketing herbs and spices to provide an alternative exportable crop for the local farmers. Zunil is also located approximately $50 \mathrm{~km}$ from the Pacific Coast where 


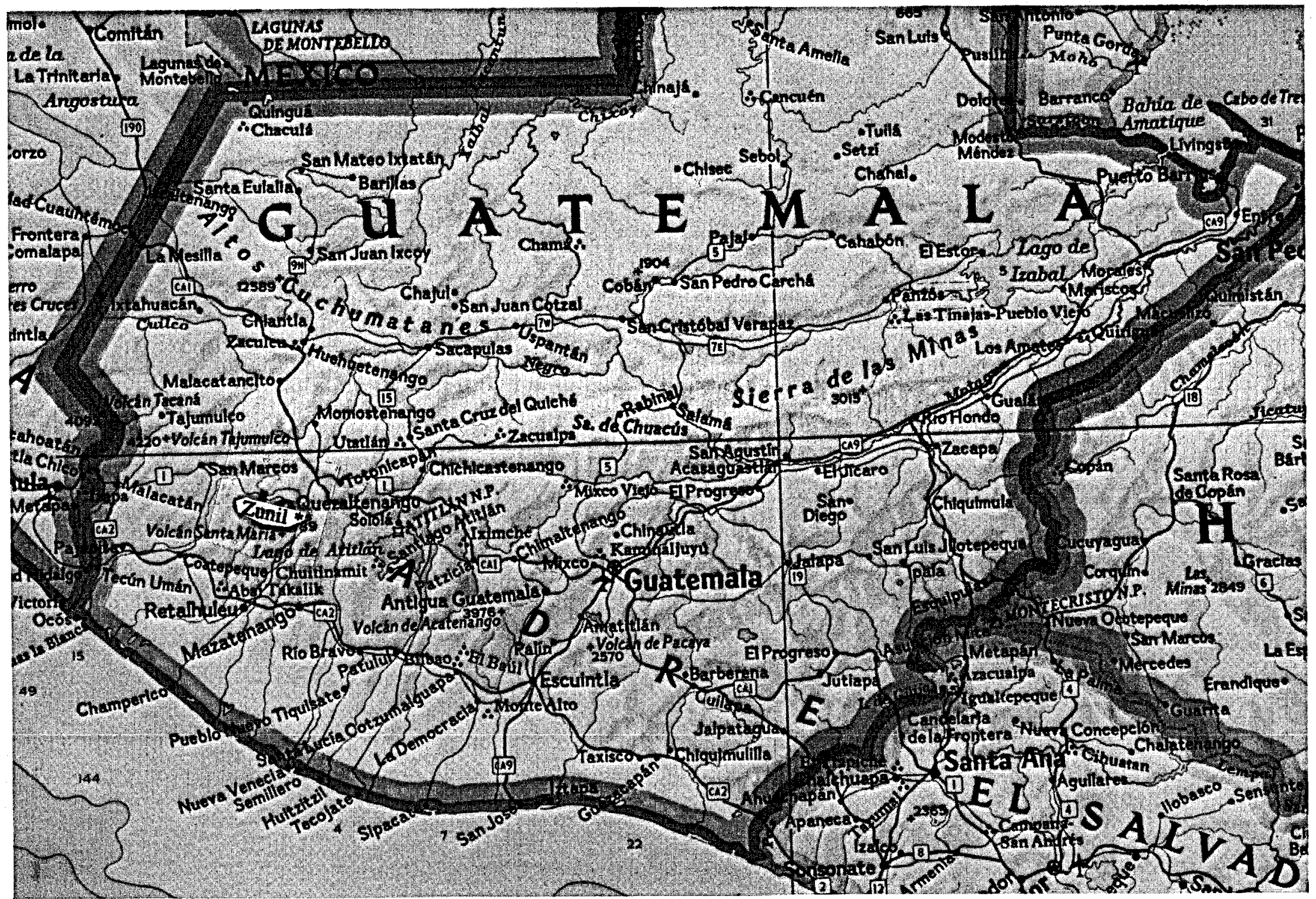

Figure 1. Map of southern Guatemala showing location of Zunil Geothermal Field. 


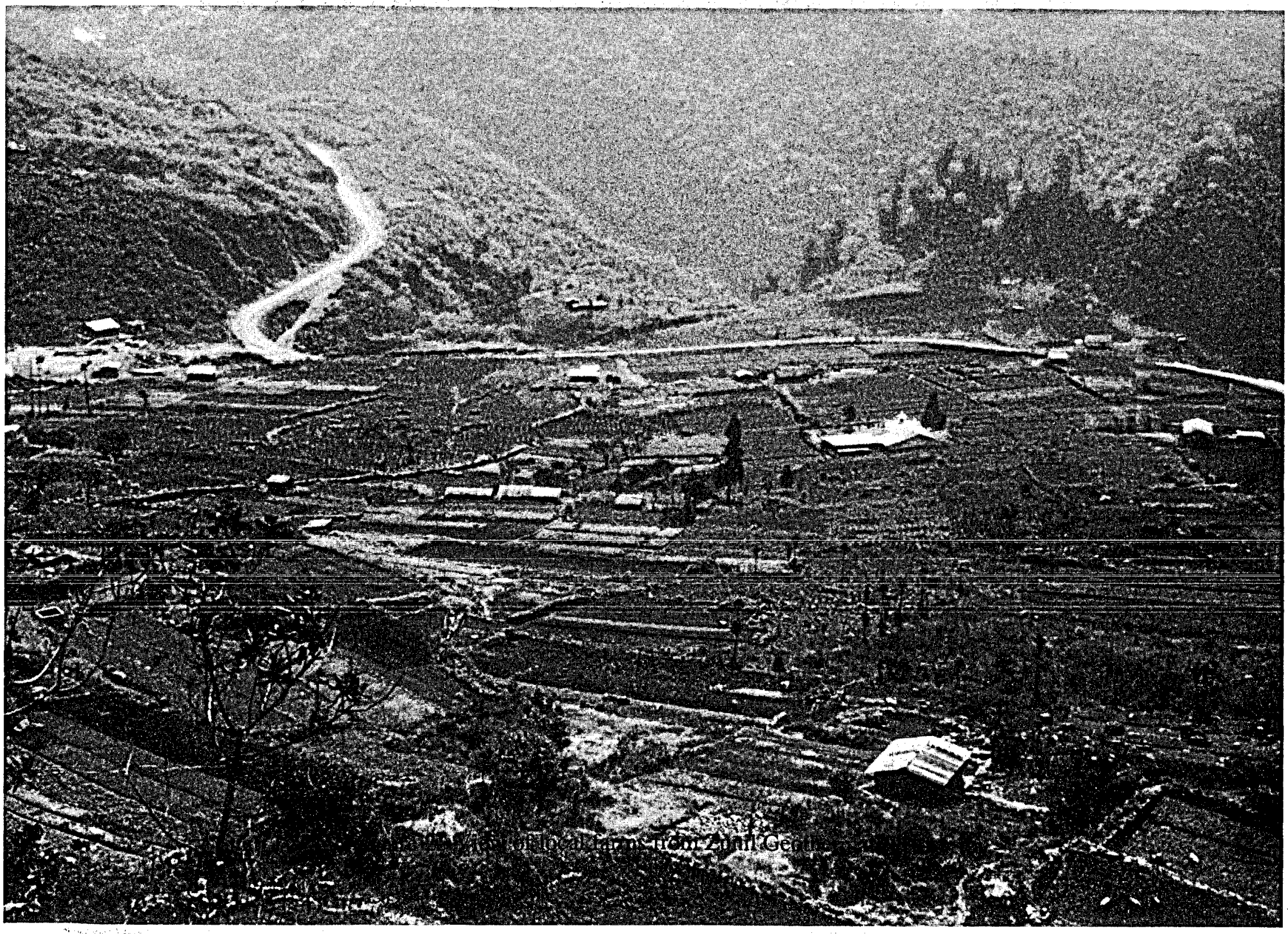




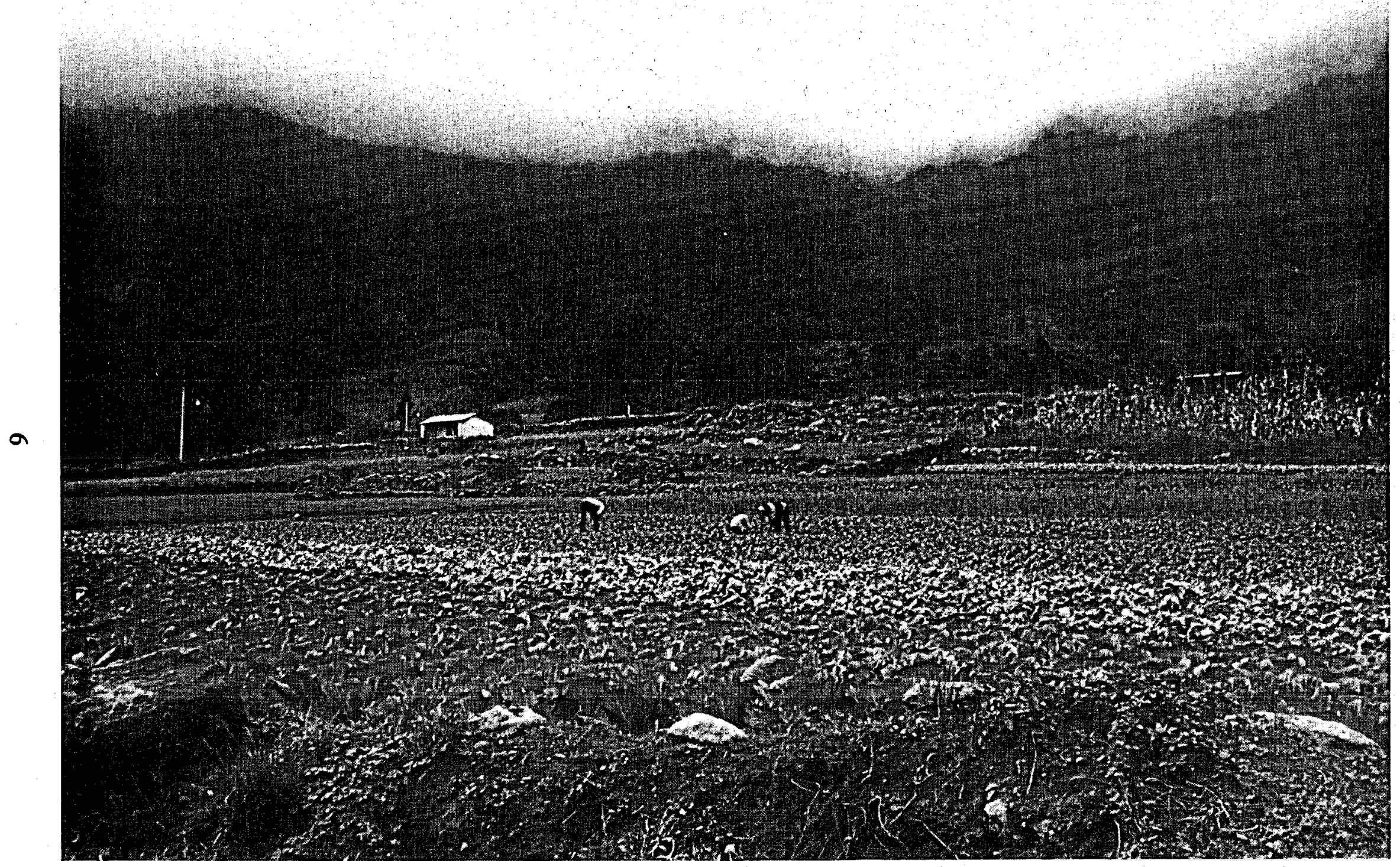

Figure 3. Crops grown next to the Zunil.Demonstration Geothermal Dehydration Facility. 
tropical products such as mangos, bananas, sugar cane, papaya, and cashews are grown. Thus, the location of the facility provides a variety of products that can be processed in a dehydration facility.

The original focus of the project was to quickly demonstrate the feasibility of using geothermal energy in industrial applications. Because of the agricultural market conditions at Zunil, the original idea of a crop drying facility would not have much application in the area, but a food dehydration facility would give area farmers a new market for their produce and would use product seconds which were being discarded. The change from a crop drying facility to a dehydration facility involved considerable changes in the scope of the project because the energy, temperature, air flow, and process control requirements are more stringent for a dehydration facility than for the proposed crop drying facility. Because Zunil is located at the heart of an area with a climatic range from temperate to tropical capable of producing a wide variety of crops, the facility was designed to be operated over a wide range of processing conditions.

The Zunil Geothermal Field consists of several production wells and a few slim-hole exploratory wells. The demonstration facility requires little energy, but to supply what is required, a production well would need to run at full power, wasting considerable geothermal energy and depleting the field intended for electrical production. Thus, instead of a production well it was decided to use Well Z-11, a slim-hole exploratory well that had been drilled early in the Zunil Geothermal Field development and was uncontrolled. The Instituto Nacional de Electrificacion (INDE) subsequently controlled the well and constructed a valve bank, silencers, and a steam separator, allowing the well to provide steam for the demonstration facility. However, use of Well Z-11 did add some additional difficulties to the design and construction of the demonstration facility because the well was located in the bottom of a canyon (Figs. 4 and 5). Considerable effort was required to design and construct the hot water loop that would bring energy from the well in the bottom of the canyon to the facility located at the top. And because of flooding in the canyon, supports for the heat loop were washed out and had to be redesigned.

The Zunil facility was constructed in cooperation with INDE. The agreement for the project delegated the responsibility for designing and purchasing materials for the facility to Los Alamos. INDE was responsible for providing the labor and management for construction of the facility. The Gremial de Exportadores de 


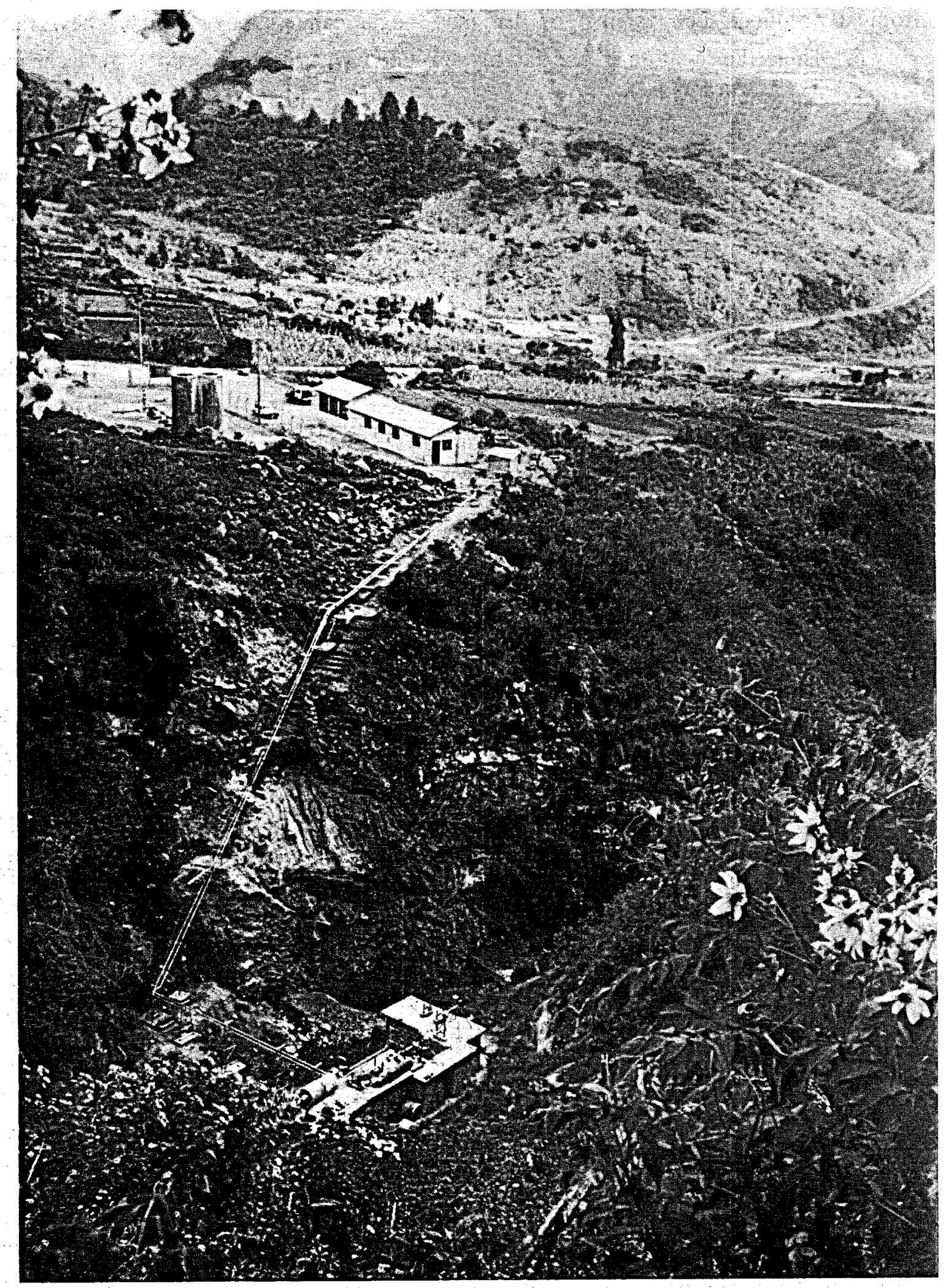

Figure 4. The Zunil Demonstration Geothermal Dehydration Facility, Well Z-11 located in canyon, and connecting hot water loop. 


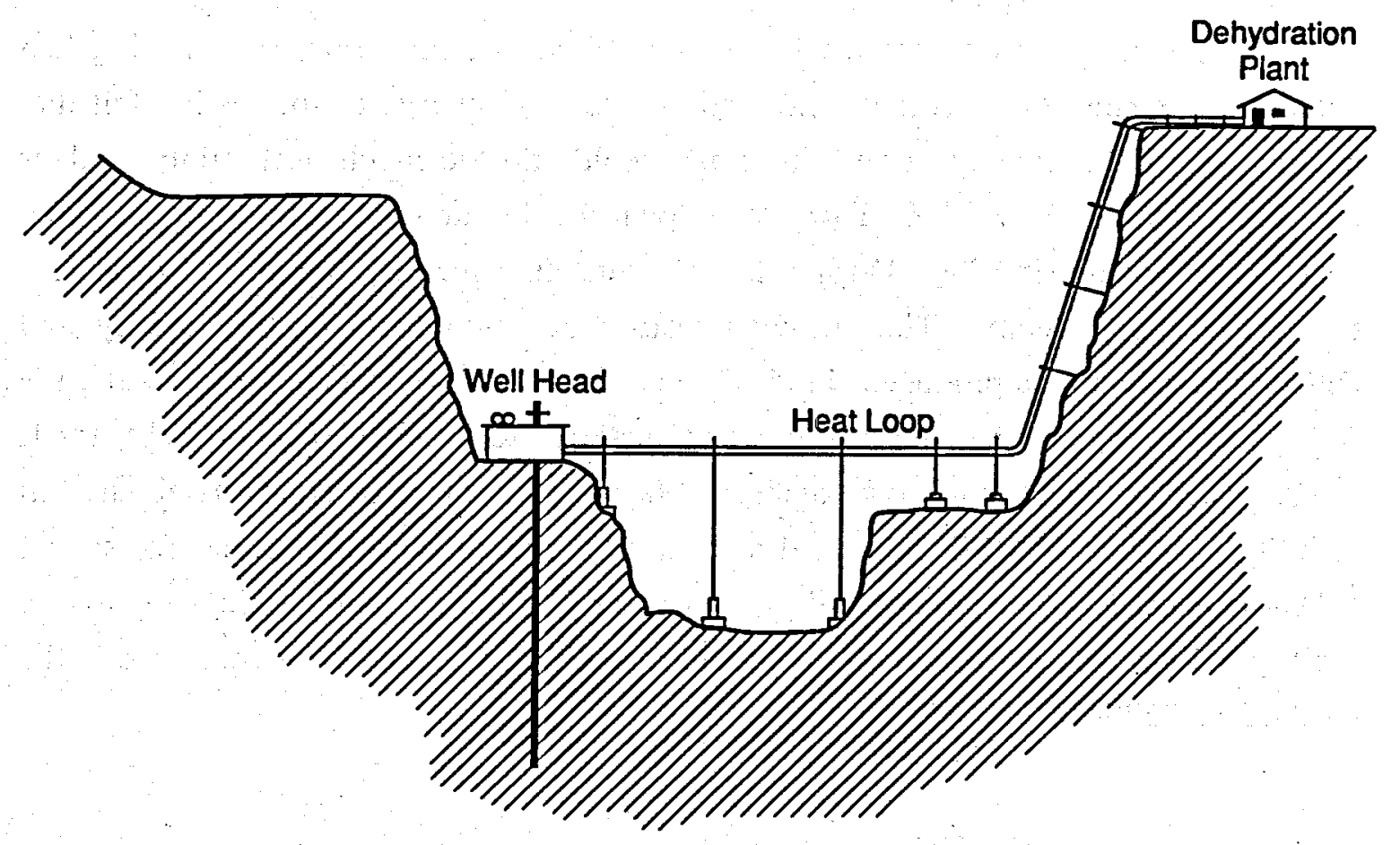

Fig. 5. Elevation change for hot water loop route. 
Productos No Tradicionales, a trade union, was contracted to operate the facility when it became operational. However, because of strikes by INDE personnel and other delays in the project, the later stages of construction were under the supervision of Oscar Maldonado, the plant manager hired by the Gremial. Construction was completed by Consultecnia, a consulting firm owned by Mr. Maldonado, because the trade union contract expired.

The facility was completed in January 1989. At that time, flow testing had begun on the Zunil Geothermal Field, and engineers in charge of the testing felt that having Well Z-11 flowing during this time would add too much uncertainty to their measurements. Thus, Well Z-11 was shut down for the duration of the testing, which lasted until November 1989. During this time the Zunil facility was operated using a boiler to supply steam. This allowed testing of some parts of the facility and dehydration of various products. In November, Well Z-11 was opened and testing the full system continued until the facility was transferred to MOSCAMED on February 1, 1990. Well Z-11 was shut down again in May 1990 because of concerns about well stability but MOSCAMED continued to operate the facility using a boiler for steam. When the electrical generating facility planned for Zunil is operational, the dehydration facility will be able to switch to geothermal energy using waste heat from the production well located next to it. 


\section{FACILITY DESIGN}

\section{A. General}

A general schematic of the Zunil Geothermal Demonstration Food Dehydration Facility, as built, is presented in Fig. 6. A schematic of the original design (Fig. 7) shows the addition of a bin dryer and control valves. Steam is separated from the mixed flow of steam and water exiting the well. This steam is used in a steam-towater heat exchanger where the steam is condensed and heats water in the hot water loop. The hot water is then pumped through a 2-in. pipe to the facility where heat for the drying tunnel is extracted in a water-to-air heat exchanger. The air in the dehydration tunnel is drawn from outside and is circulated using a blower. There is also a provision for another hot water loop, originally planned to be a bin-type dryer, but because of cost considerations it was never constructed. After flowing through the air-to-water heat exchangers, the hot water loop water goes through a single-pass, water-to-water heat exchanger. This heat exchanger provides hot, potable water for the plant. The water then returns to the primary heat exchanger. Thus, the facility has provisions for two driers, one high-capacity tunnel type and one lower-capacity bin type, and can heat potable water with geothermal energy. The design temperatures in the facility are

$120^{\circ} \mathrm{C}$ - steam entering steam-to-water heat exchangers,

$109^{\circ} \mathrm{C}$ - hot water loop water exiting well head heat exchanger,

$65^{\circ} \mathrm{C}$ - air exiting dehydrator heat exchanger, and

$30^{\circ} \mathrm{C}-$ maximum hot water loop temperature drop.

The dehydration tunnel has a cross section of 1 by $1.4 \mathrm{~m}$. Air flows through a screened opening into the blower inlet plenum, a backward-incline wheel blower, and a diverging blower exhaust nozzle, then through a constant-cross-section dehydration tunnel and out of the building through a wall opening. The air velocity in the tunnel was measured to be $600 \mathrm{cu} \mathrm{ft} / \mathrm{min}$. The tunnel is instrumented with an air flow meter, humidity meters, and thermocouple probes for temperature measurements. Provisions were also made for automatic control of the tunnel air temperature using an air temperature probe and control valves on the exit side of the air-to-water heat exchanger. However, problems were encountered with rust particles clogging the control valves, and so the automatic controls were not used during most of the facility's operation. The product to be dehydrated is loaded on carts that can be rolled 


\section{PIPING AND HEAT LOOP SCHEMATIC}

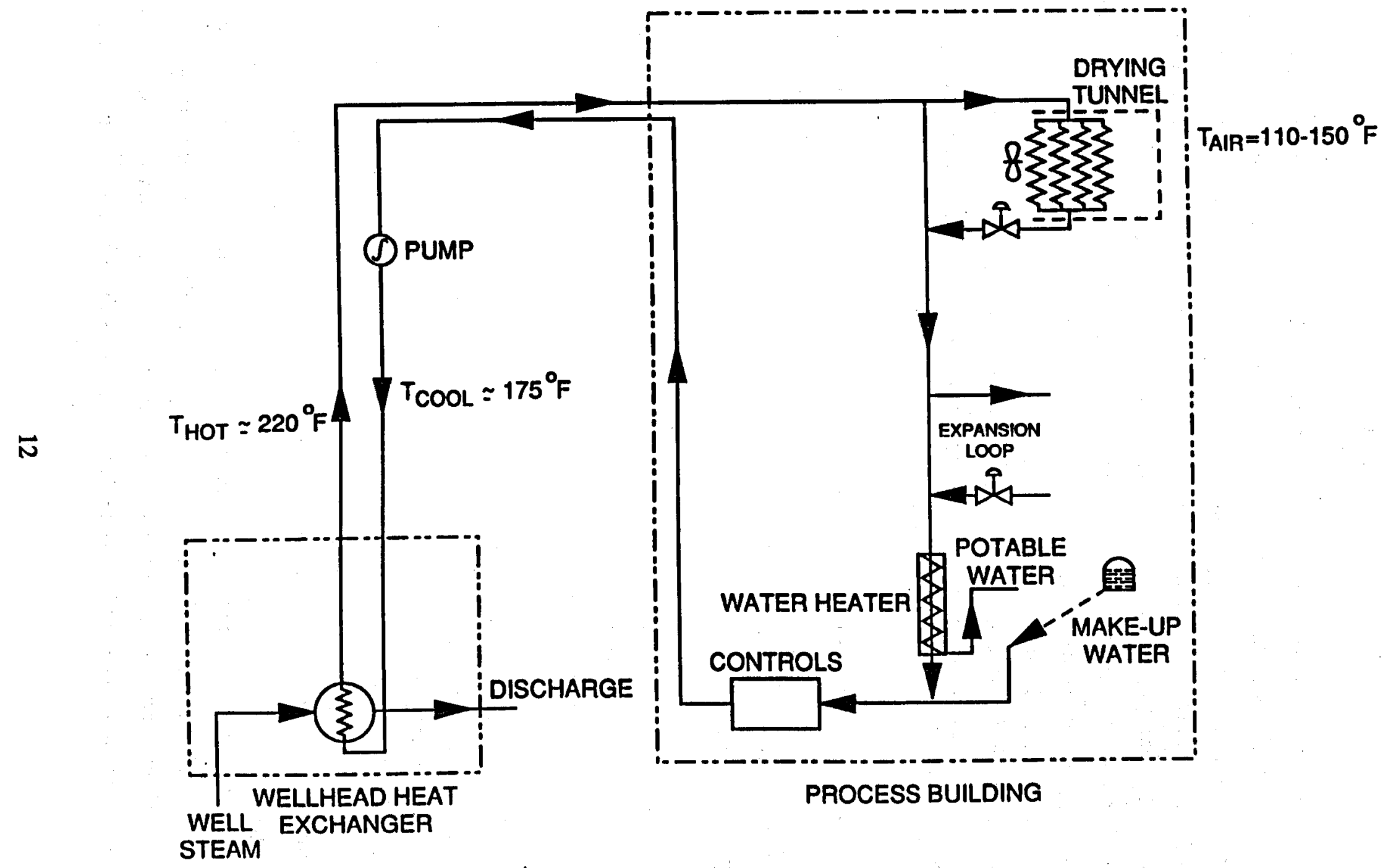

Figure 6. Schematic For Zunil Demonstration Geothermal Dehydration Facility. 


\section{PIPING AND HEAT LOOP SCHEMATIC}

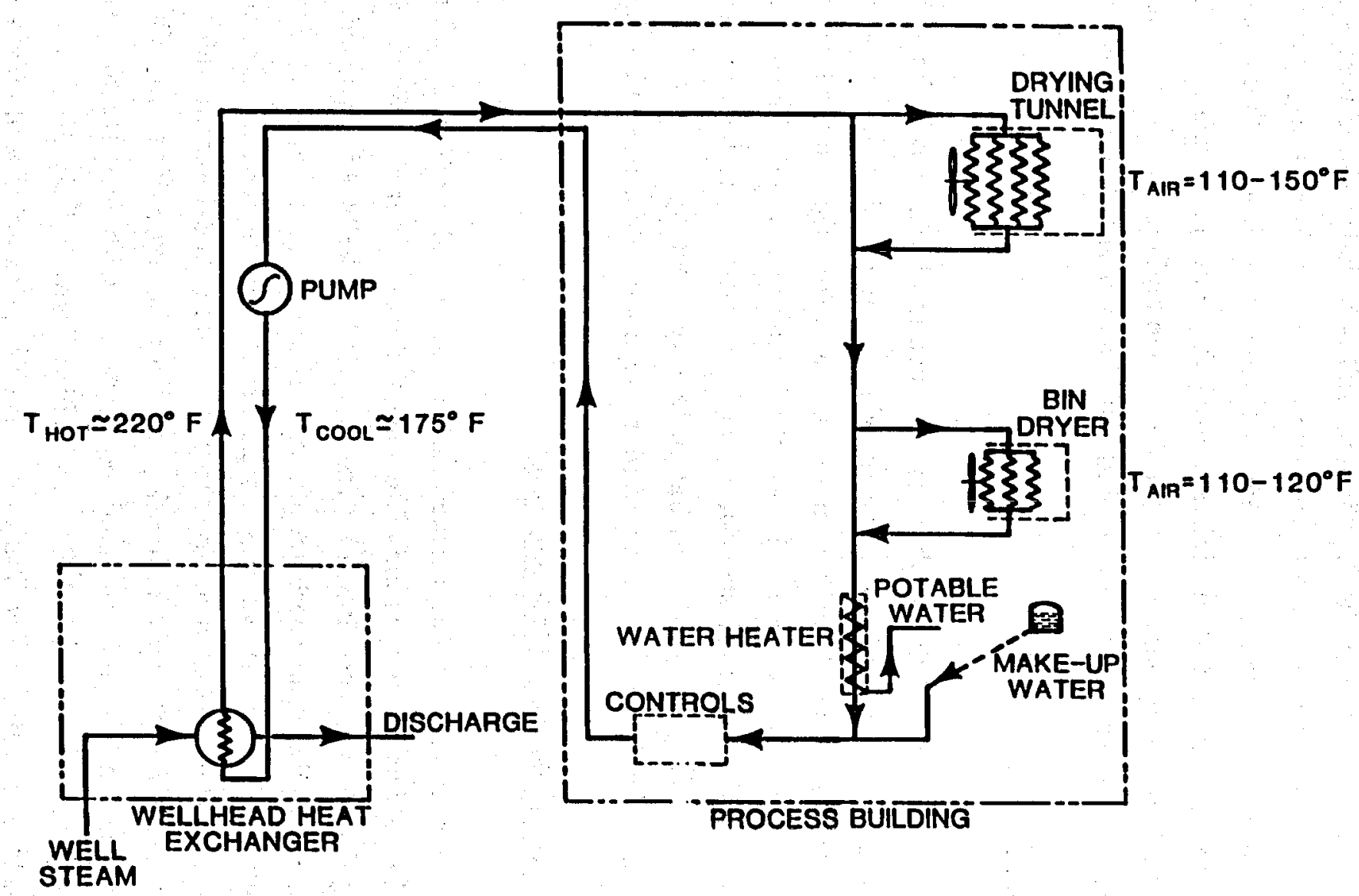

Figure 7. Original design schematic for Zunil Geothermal Demonstration Dehydration Facility. 
into the tunnel. The product is then loaded on $89-\mathrm{x} 50-\mathrm{cm}$ screens with 36 screens to a cart. The tunnel will hold a maximum of 7 carts, allowing a maximum product load of approximately $730 \mathrm{~kg}$ of heavy items such as bananas.

The work space in the dehydration facility includes a food processing room with ceiling-mounted water and electric connections, a food storage room, a product storage room, lunchroom, restroom, and shower facilities. Stainless-steel-covered tables and a stainless steel sink are used for food processing. Potable water is provided from springs and is stored in a concrete holding tank located above the plant. Equipment has been installed to provide chlorination of the potable water.

\section{B. Wellhead}

A schematic of the wellhead is presented in Fig. 8. Mixed flow exiting the well is separated into two streams, one of which is released to the atmosphere through silencers. The other stream is input into a steam separator where steam for the dehydration facility is separated from the geothermal water. The separated steam is then put through an HX-1 steam-to-water heat exchanger to heat the water in the hot water loop that goes to the dehydration facility. During full-power operation of the dehydration facility, all the steam from the separator condenses in the heat exchanger.

\section{Wellhead and Heat Loop Interface}

Well Z-11 produces a mixed flow of steam and water of 3200 to $3600 \mathrm{~kg} / \mathrm{h}$. This mixed flow is divided almost evenly between steam and water. The fixed-flow well production is split into two fractions at the wellhead. The larger fraction is discharged to the atmosphere and the run-off ditch through a silencer/weir subsystem. The smaller fraction flows into a steam separator subsystem. The resultant steam flows into the HX-1 heat exchanger through a 3-in-diam line. The design requirements for the dehydration facility were $500 \mathrm{~kg} / \mathrm{h}$ of steam. Once testing was under way, the facility operated satisfactorily with less steam. During normal operation the steam used in $\mathrm{HX}-1$ represented approximately $8 \%$ of the total energy in the water and steam exiting the well. To obtain this amount of steam, approximately $20 \%$ of the mixed flow from the well was routed to the steam separator. The flow in the two loops was controlled by inserting orifices in the line leading to the steam separator. INDE personnel balanced the flow in the two lines so that steam required 


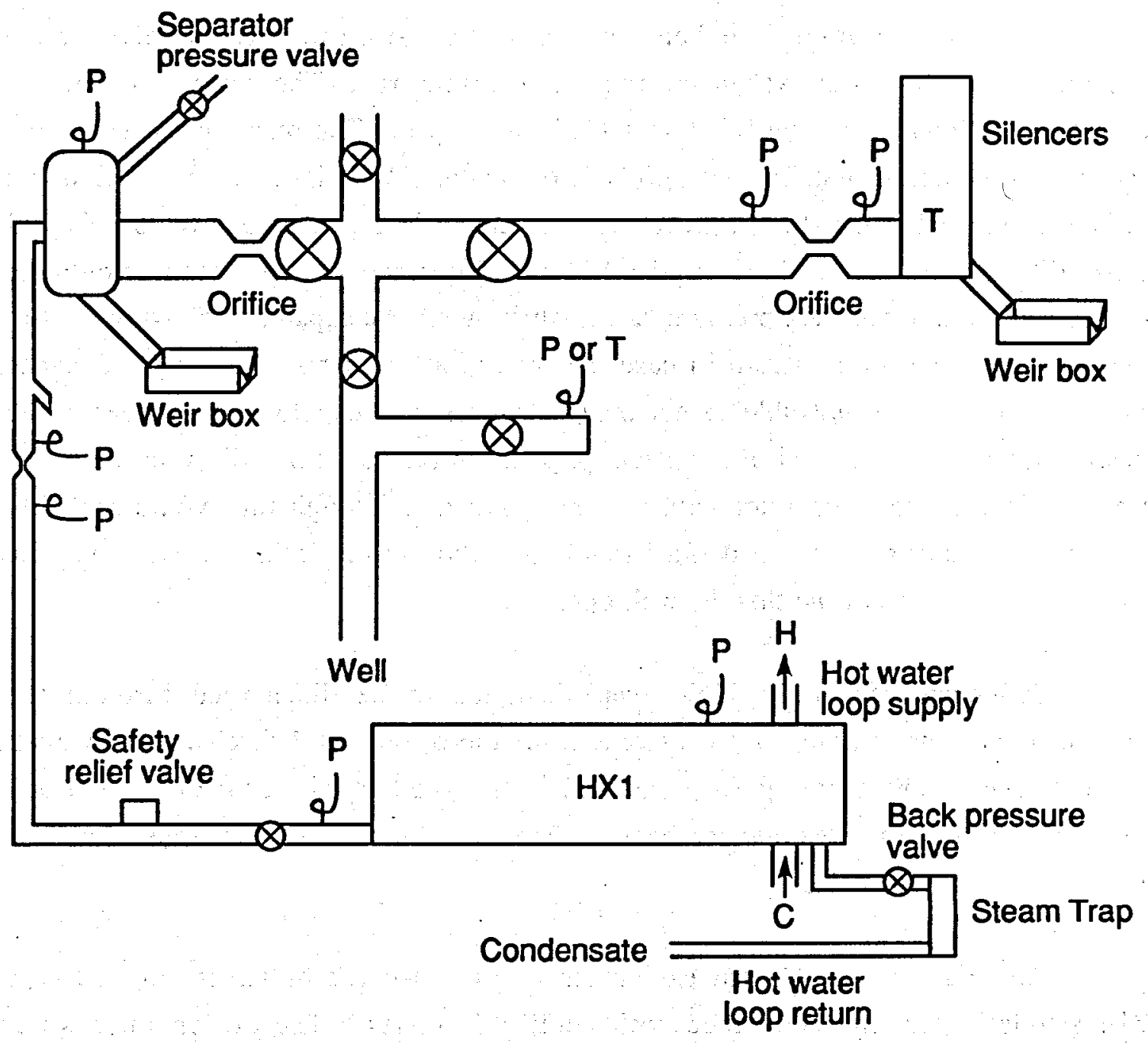

Fig. 8. Wellhead schematic. 
for the facility operation exited the steam separator. Other parameters of the fluid exiting the well were 90 to $100 \mathrm{psi}$ - wellhead pressure, $165^{\circ} \mathrm{C}$ - fluid temperature, and 5 - fluid $\mathrm{pH}$. The geothermal fluid is released into the air as steam or into the canyon as water or condensate.

The steam separator line from the well contained a safety relief valve, steam separator, the HX-1 heat exchanger, and a condensate trap. The design temperature of the steam flowing into the $\mathrm{HX}-1$ was $116^{\circ} \mathrm{C}$ at 25 psia. The maximum design flow rate for the geothermal steam was $500 \mathrm{~kg} / \mathrm{h}$ of steam. The original design included a back-pressure valve installed to keep the pressure in HX-1 at or below 25 psia and thus, the temperature at $116^{\circ}$ in the $\mathrm{HX}-1$. The uncondensed steam would be discharged through the back-pressure valve, which would be capable of flowing the full $500 \mathrm{~kg} / \mathrm{h}$ design flow of steam in case the water loop was not operating. Because plant personnel were not able to get the back-pressure valve to work properly, the design was modified to control the steam pressure in the HX-1 by adjusting the steam pressure in the steam separator with a manual valve. Although this would probably not be satisfactory for long-term and variable operation of the facility, it was adequate for the short period of time that the well operated.

Condensate from the HX-1 was designed to be discharged through the automatic condensate drain. A small vent at the top of the $\mathrm{HX}-1$ discharged the small amount of noncondensable gases contained in the geothermal steam to prevent any interference with the steam/water heat exchange process. All discharge vents use mufflers to suppress noise.

The HX-1 wellhead heat exchanger was constructed of stress-relieved type 316 stainless steel in accordance with applicable codes. The design inlet water temperature was $79^{\circ} \mathrm{C}$ and the design water outlet temperature was $109^{\circ} \mathrm{C}$. The inlet and outlet temperatures were expected to vary depending on changing demand for heat in the processing plant.

The maximum design steam temperature of $116^{\circ} \mathrm{C}$ (designed to be controlled by the back-pressure valve) was selected so that the maximum water temperature in the hot water loop would be less than $116^{\circ} \mathrm{C}$. It is desirable to keep the water temperature below the value in the hot water loop to prevent effects such as 
excessive corrosion or seal damage. Therefore, operation of the hot water loop at temperatures greater than $116^{\circ} \mathrm{C}$ is not recommended.

Although the flow from the well to the steam separator and the HX-1 might be turned on or off, the preferred mode of operation was for the flow from Well Z-11 to be maintained constant at essentially full flow at all times to prevent erosion of the valve gates and to prevent pressure changes in the well that might shorten the life of the well. Although the back-pressure valve was not used to control the steam pressure during the actual operation of the well, the well was maintained at a constant full flow. The steam pressure and thus the temperature in the HX-1 was controlled by bleeding off steam in the steam separator, thus reducing the steam pressure in the HX-1.

\section{Hot Water Loop}

Since Well Z-11 does produce low-pressure steam, it would have been possible to transfer energy from the well to the plant by means of a steam line. However, when geothermal steam is available, the application of first choice is usually to drive a turbine to generate electricity rather than utilize it for moderate-temperature industrial applications. In keeping with the idea that the Zunil plant is meant to demonstrate the most generic and typical geothermal systems, it was decided to use a water loop to transfer the heat from the well to the plant to duplicate the most likely conditions that would exist if the plant were using waste heat from a geothermal electrical power plant.

The hot water loop was approximately $100 \mathrm{~m}$ in length and was constructed of iron pipe. Circulation was provided by two 3/4 HP pumps connected in parallel. Strainers were located before the input of each pump to keep large particles from entering the pump, and an air trap was built into the pipe. The pipe was insulated with fiber insulation wrapped with metal sheets to keep out moisture and rain water. Dielectric unions were used between the heat exchanger and the loop piping to prevent electrochemical corrosion. Two loop pressurization tanks were incorporated in the original design to control the loop prèssure.

A dual pump system was installed close to and downstream of the plant. The combined outflow of the pumps can meet the design water flow rate. Flow rates can 
be lowered by shutting off one pump and also by changing the pressure drop across the loop. The pumps contain 3/4 HP motors and will each operate efficiently over a 11- to 40 -gram / min range with total head output of $38 \mathrm{psi}$ to $16 \mathrm{psi}$. The pumps have special high-temperature seals. Suction and discharge pressure shutdown switches were included to prevent pump damage in case of flow malfunctions in the water loop.

The hot water loop presented one of the major problems in constructing the facility. The well was located in the bottom of a canyon (Fig. 5), but the facility was located on the side of the canyon. Thus, the hot water loop had to traverse the side of a steep canyon which made it difficult to support the length of the pipe properly. And, one of the supports in the bottom of the canyon was also washed out during some of the extraordinary rains that occurred. This required the design and construction of alternative supports for the pipeline across the canyon. The operating parameters for the hot water loop were

$120^{\circ} \mathrm{C}$ - water temperature exiting the $\mathrm{HX}-1$,

$104^{\circ} \mathrm{C}$ - water temperature entering the $\mathrm{HX}-1$, and

$40.5 \mathrm{gpm}$ - water flow rate.

The hot water loop supplies energy for the dehydration tunnel and for heating potable water for hot wash water. Also, provisions have been made for an additional dryer that can be operated from the hot water loop.

The original design of the hot water loop included automatic control valves for controlling air temperature in the dehydration tunnel (Fig. 9). The automatic control valves were to control the flow of hot water through the water-to-air (HX-2) heat exchanger. A temperature sensor was to be located in the tunnel. This sensor would control the opening and closing of the valve in the exit of the HX-2. The control temperature could be set manually with a knob on the control valve. A bypass loop with a spring-loaded check valve allowed water to continue flowing in the loop when flow to the HX-2 was restricted and pressure in the hot water loop increased. However, because of problems with corrosion and rust in the hot water loop piping, the control valves would plug rapidly, stopping flow to the HX-2. Therefore, the valves were removed from the loop. Air temperature in the tunnel was regulated by controlling the water temperature in the hot water loop. Water temperature was regulated by controlling pressure in the steam separator and, thus, the amount of steam that entered the HX-1. This was done to allow dehydration demonstrations to proceed during the short period that Well Z-11 was operational. 


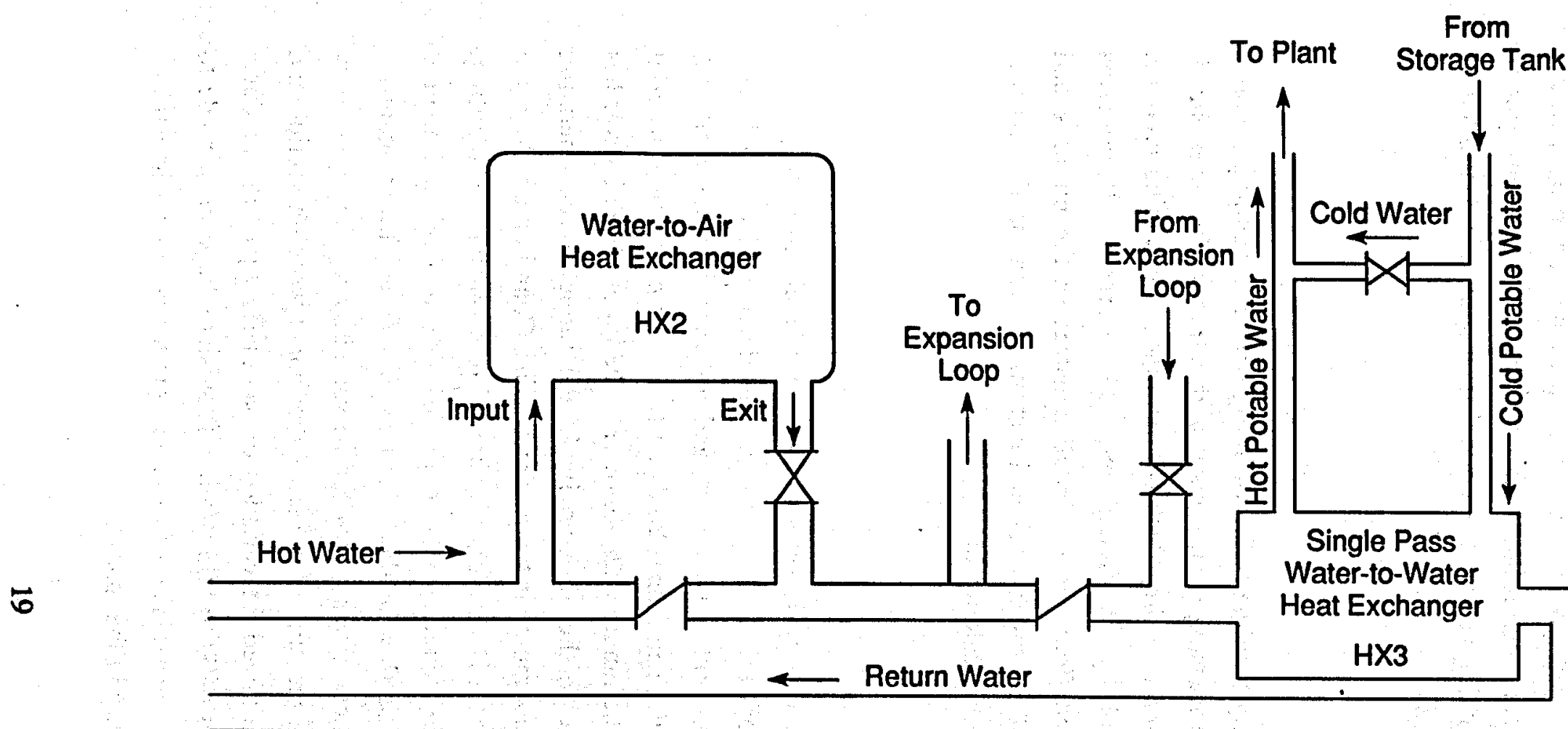

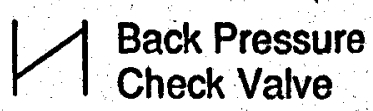

$\$$ Mixing valve (automatic)
Х Air temperature Controlled Valve

X Automatic Control Valve, controlled by air temperature in tunnel

Figure 9. Diagram of original design for automatic control of tunnel temperature. 
The hot water loop also provides energy to heat water for the facility. The water in the hot water loop flows through a single-pass heat exchanger with potable water on the secondary side of the heat exchanger. The hot potable water exiting the heat exchanger is mixed with cold potable water to provide the proper water temperature. Mixing is automatically controlled with a mixing valve and temperature sensor on the output side of the mixing valve. The control temperature is controlled by a knob located on the control valve.

\section{E. Dehydration Facility}

The floor plan of the facility building is shown in Fig. 10. The building contains the dehydration tunnel, a food processing area, shower and bathroom facilities, lunch room, a storage/laboratory area, and a loading dock with storage for incoming produce. The building was designed jointly by INDE and Los Alamos. It contains approximately $80 \mathrm{~m}^{2}$ of enclosed floor space. INDE constructed the building and installed the equipment. Much of the finish work and instrumentation installation was done under the supervision of Oscar Maldonado.

\section{E. Dehydration Tunnel}

The dehydration tunnel is a $1-$ by $1.4-\mathrm{m}$ cross section tunnel $7.8 \mathrm{~m}$ long. The floor is a concrete slab and the walls and ceiling are insulated and covered with corrugated iron sheeting. It is a single-pass tunnel, and no provision was made for recirculating air exiting the tunnel. The tunnel holds up to 7 carts containing material to be dried. Air is blown down the tunnel with a blower. The input of the blower has shutters that allow some change in the air velocity in the tunnel. The operating parameters for the tunnel are a maximum air temperature of $65^{\circ} \mathrm{C}$, and an air flow rate of $600 \mathrm{cfm}$. Input air for the tunnel is ambient air drawn from outside the building, which, after passing through the tunnel, exits to the outside through a louvered window. The maximum design air flow of the blower is $10100 \mathrm{cu} . \mathrm{ft} / \mathrm{min}$ against a back pressure of 1.5 inches of water. The air flow can be varied by regulating the flow of the inlet air and/or varying the pressure drop across the tunnel working section and tunnel exit. The original design allowed for variation of the air flow past the products being processed in the tunnel from 400 to $900 \mathrm{ft} / \mathrm{min}$. Provisions have been made to measure humidity at the entrance and exit of the tunnel, air temperatures at various places in the tunnel, and air velocity in the tunnel. 


\section{PILOT DEHYDRATION PLANT}

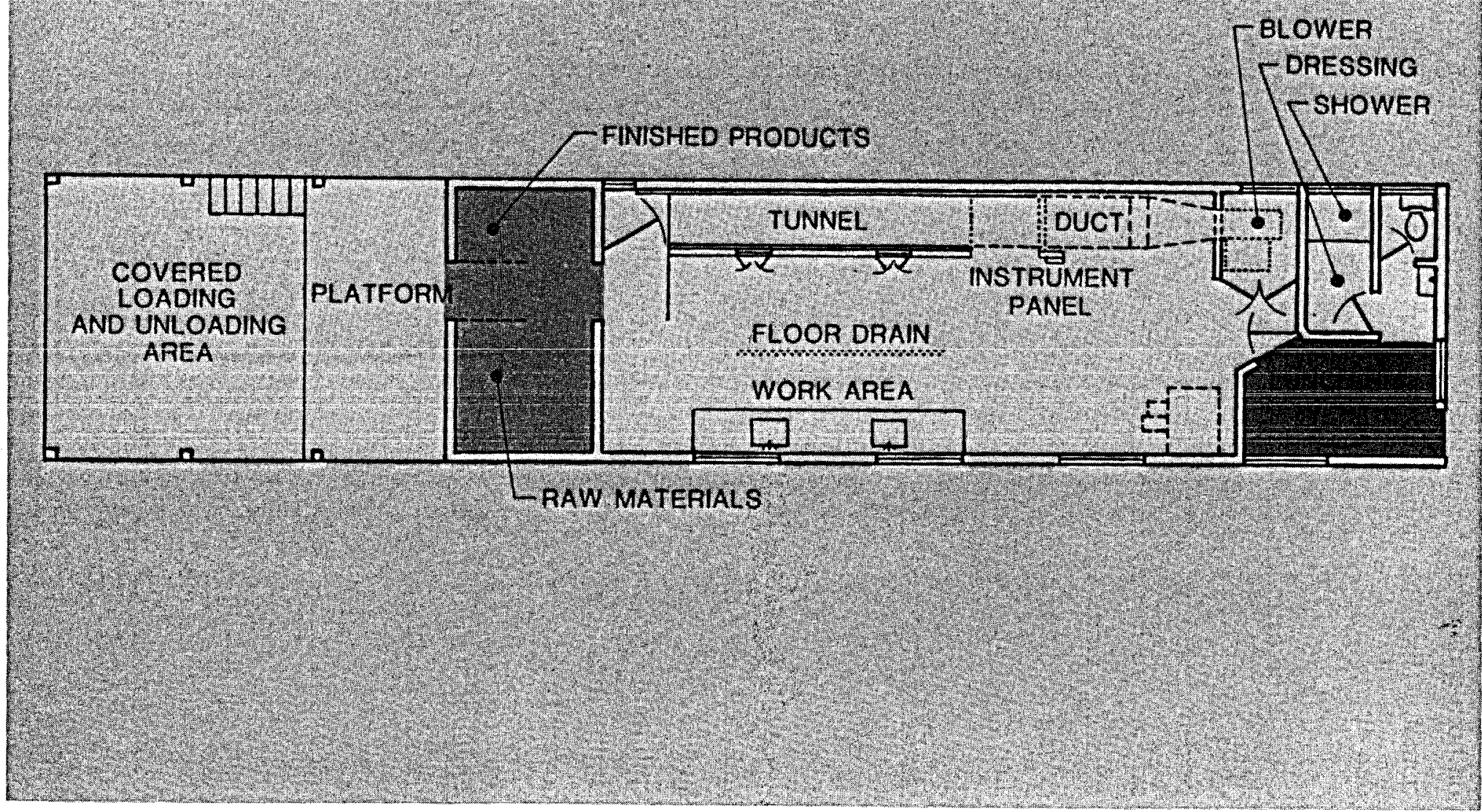

Figure 10. Zunil Facility floor plan. 
As shown in Fig. 11, a plenum is provided for the smooth transition of the air from the exit of the blower to the full cross section of the tunnel. Doors are provided on both ends of the tunnel to allow carts to be inserted or removed at either end of the tunnel. Thus, the tunnel can be operated as either a parallel-flow or a counter-flow dehydrator.

The carts that hold produce to be dehydrated have dimensions of approximately .9 by 1.02 by $1.22 \mathrm{~m}$ and have four wheels to allow ease of movement. The product to be dehydrated is loaded on removable .89 - by $1-\mathrm{m}$-wide aluminum screens and these screens are loaded 36 to a cart. Each cart can hold approximately $100 \mathrm{~kg}$ of wet produce. Grab windows were placed in the side of the tunnel so that samples of the drying product could be obtained at two points in the tunnel. Temperature, humidity, or air-velocity probes could also be inserted at these two points.

\section{G. Food Processing Area}

The food processing area (Fig. 12) is located adjacent to the entrance of the dehydration tunnel. It is designed as a clean area for preparing food for dehydration and packaging the dehydrated products. The floor and walls are clear of obstructions and can be washed with a spray. All water and electrical connections are on the ceiling to eliminate water hoses or electrical wires on the floor. A stainless steel sink is provided for washing incoming products and the equipment. Stainless-steelcovered tables are provided for preparation of the products. The floor of the foodprocessing room is a concrete slab with a rectangular drain running about half the length of the room to drain wash water. Fluorescent lights provide light. All windows are screened to prevent entrance of insects.

\section{H. Auxiliary Areas}

A loading dock and weighing area are provided for receiving and weighing incoming produce. Cabinets for storing incoming products are also located on the loading dock. These cabinets can also be used to store fruit to allow it to ripen sufficiently for processing. 

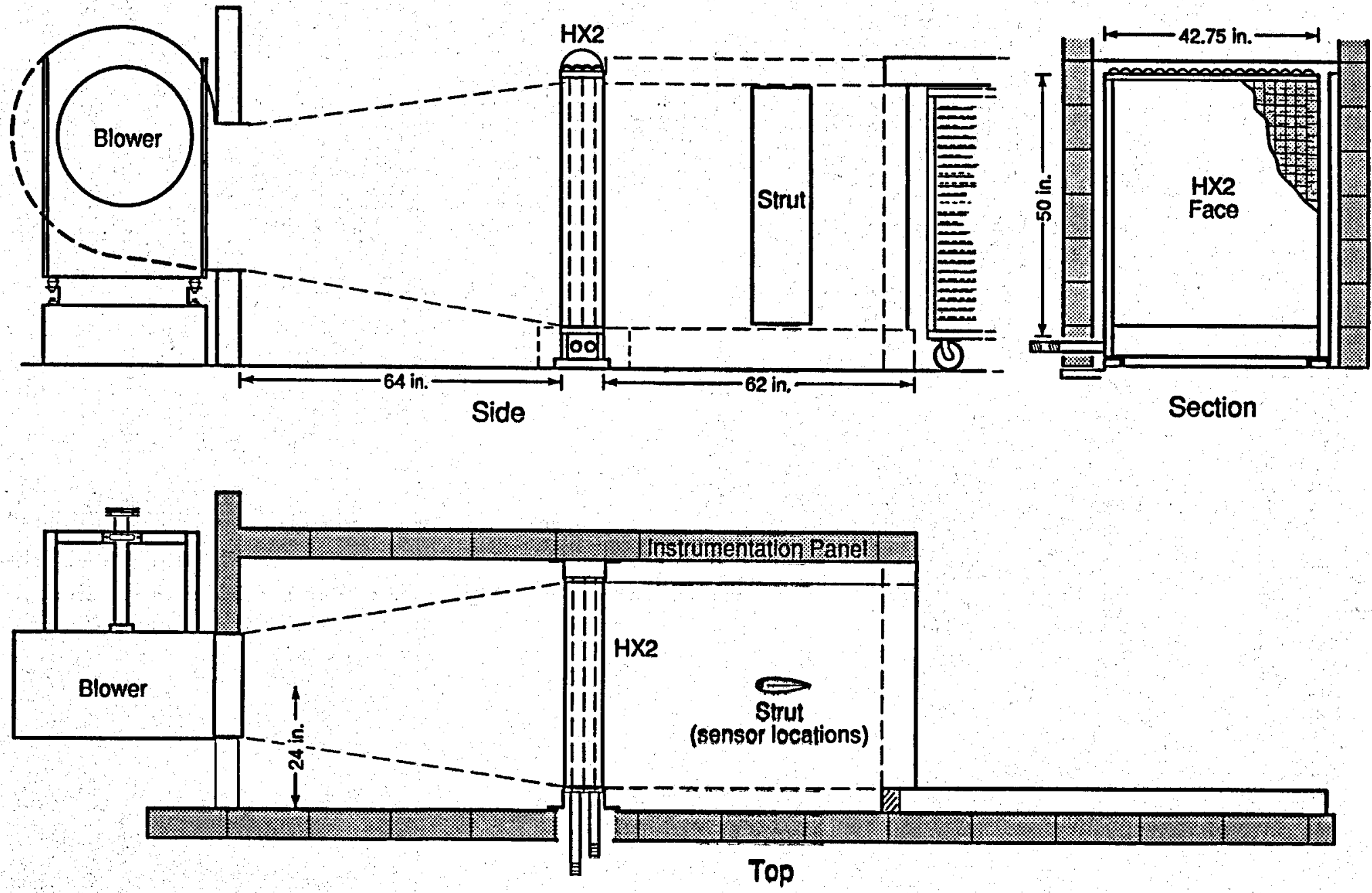

Flgure 11. Schematic of dehydration tunnel. 


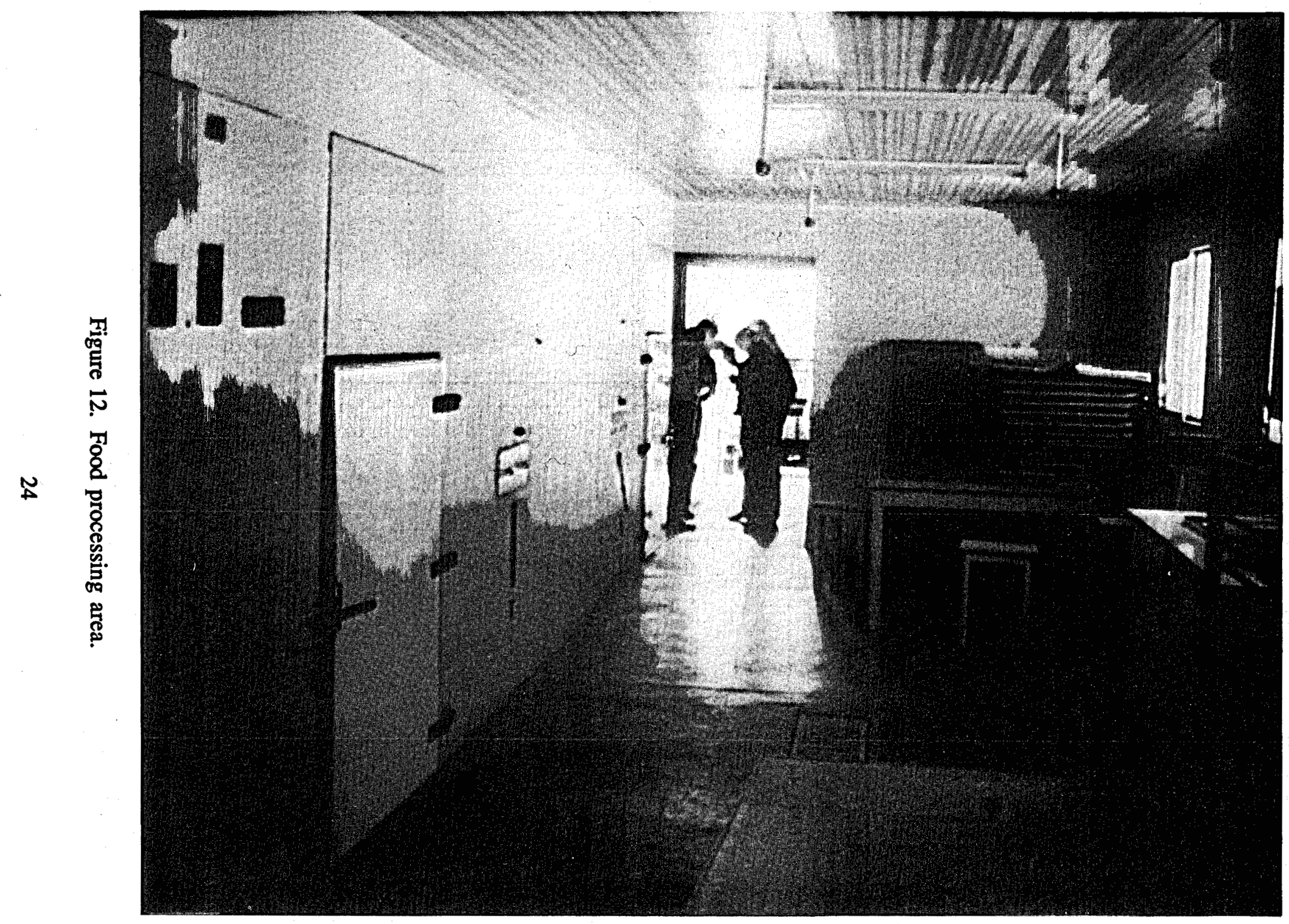


A laboratory was built to test produce in the stages of processing. It has a small dehydrator to allow some preliminary testing before the product is processed in the dehydration tunnel. In the future, equipment will be installed for measuring moisture levels and for quality control. The laboratory is also used to store dehydrated products and it also contains a wash room, shower, and lunchroom.

Small outbuildings enclose the pump area and protection from rain is provided for the valve and control bank located outside the building.

\section{Utilities}

The potable water supply comes from springs located near the site. The water supply is stored in a concrete cistern located at a higher elevation than the plant, thus allowing water to flow to the plant by gravity feed. An agreement was made with the owner of the spring to allow the plant to fill the cistern at night to avoid disrupting the owner's daytime irrigation requirements.

The water has been tested for mineral content and no harmful minerals have been found. A system has been constructed to chlorinate the water. It contains a solenoid valve that controls the water input into the cistern, operated automatically from level sensors in the cistern. When water is added to the tank, a metering pump adds a measured amount of chlorine solution. This system was not used because of the arrangement with the owner of the spring for filling the tank at night.

Both single-phase and "delta" three-phase electrical power is available at the plant. The power line is maintained by INDE.

\section{Boiler}

The facility has been equipped with two boilers. The first boiler used for the initial testing of the plant was rented locally. This boiler was diesel-fueled and rated at $15 \mathrm{hp}$. The boiler was connected directly to the HX-2, and tests were also run with this boiler supplying steam to the HX-1, which had been moved closer to the plant. This operation allowed testing of the complete hot-water-loop and heat-exchanger system in preparation for the opening of Well Z-11. 
When Well Z-11 was opened for testing, the rented boiler was returned. Because additional shutdowns were anticipated, a boiler was purchased for the facility so that operation could continue even without Well Z-11. The purchased boiler was rated at $30 \mathrm{hp}$ and could produce $1700 \mathrm{lb}$ of steam per hour at $125 \mathrm{psig}$. This boiler was installed at the facility shortly after MOSCAMED assumed responsibility for operating the facility and was used for steam when Well Z-11 was turned off in May 1990. 


\section{OPERATIONAL EXPERIENCE}

\section{A. General}

The information presented in this section was obtained during the operation of Well Z-11 and during dehydration tests. The data was collected and analyzed by Oscar Maldonado, the plant manager. More details of these operations are given in Reference 6 (in Spanish).

\section{B. Operation of Well Z-11}

Operation of the Zunil facility using the well as a source of steam started on November 2, 1989 and continued until after MOSCAMED assumed responsibility for operation. Well Z-11 could not be used before this because of flow testing in the Zunil Geothermal Field.

After opening the well, the initial operation was to balance the flow between the steam separator leg of the well output and the leg where the steam was released to the atmosphere through silencers. Personnel from INDE, with assistance from the plant manager, did this initial balancing. Once flow from the well had been separated satisfactorily, measurements were taken of the flow on each leg of the output. On the silencer leg of the well output, the condensate flow was measured using the bucket method and using a weir. The bucket method gave a flow rate of $1800 \mathrm{~kg}$ water per hour and the weir method gave a flow rate of $1500 \mathrm{~kg}$ of water per hour.

Measurements were also made for the water exiting the steam-to-water HX-1 heat exchanger. Since all the steam entering the HX-1 was condensed, this measurement represented the total steam flow to the HX-1. The bucket method was used in this measurement and gave a value of $74 \mathrm{~kg} / \mathrm{h}$ of steam. Similar measurements were made for the condensate exiting the steam separator and a value of $345 \mathrm{~kg} / \mathrm{h}$ was obtained.

The total flow in each leg of the wellhead was calculated and added to give the total flow for the well. The mixed flow in the silencer leg of the wellhead was calculated by standard methods using the measured water flow and the assumption that the geothermal fluid was produced at a temperature of $225^{\circ} \mathrm{C}$. The total flow for 
the silencer leg was found to be $2610 \mathrm{~kg} / \mathrm{h}$. For the separator and heat exchanger leg, the total flow was the sum of flow dumped by the steam separator plus the flow of steam into the HX-1. The flow into the HX-1 was measured and the flow through the steam separator was calculated to be $485 \mathrm{~kg} / \mathrm{h}$. This, plus the $74 \mathrm{~kg} / \mathrm{h}$ of steam flowing into the $\mathrm{HX}-1$, gives a total flow in the heat exchanger leg of $514 \mathrm{~kg} / \mathrm{h}$ or a total mixed flow for the well of about $3200 \mathrm{~kg} / \mathrm{h}$. About $1020 \mathrm{~kg} / \mathrm{h}$ of this flow was steam, so the Zunil dehydration facility only used $7 \%$ to $8 \%$ of the available steam from Well Z-11. Thus, even with use of a small exploratory well for a steam supply, there is sufficient steam available to provide energy for other applications. The estimate for the heat being used by the plant was 0.188 million Btu/h or $5.5 \%$ of the total estimated energy ( 3.3 million Btu/h) being produced by the well. The amount of energy being used by the facility will depend on the ambient conditions and the air temperature and velocity in the tunnel. The heat loop system has the capability of absorbing 4 to 5 times the energy used in these operations.

At the initial opening of the well, the well mass-flow rate was measured at $2910 \mathrm{~kg} / \mathrm{h}$. After a month of operation, the flow in the well decreased about $10 \%$. However, no further decrease of the flow was observed during the remainder of the time that Well Z-11 was in operation. Tables A-1 to A-4 in the Appendix give a sample of the geothermal liquid flow values in the system. The large changes in steam utilization shown in these tables were due to the addition of insulation to the HX-1 and the reduction of the air temperature in the dehydration tunnel.

\section{Operation of the Heat Loop}

After the wellhead at Well Z-11 was balanced, tests were done on the heat loop, initially with the dehydration tunnel empty. The values measured were pressure and temperature at the intake and exit of the HX-1, shell pressure of the HX-1, wellhead pressure, water pressure at the input of the tunnel water-to-air heat exchanger (HX-2), pump suction pressure, pump discharge pressure, and water temperature at the intake and exit of the HX-2. A typical pressure in the heat loop is 30 psi and a typical temperature drop across the $\mathrm{HX}-2$ was $5^{\circ}-10^{\circ} \mathrm{C}$ when the fan was operating. The values for the temperature drop across the HX-2 were highly dependent on the ambient temperature. 
Instruments were inserted in the hot water loop to measure flow, pressure, temperature, and flow rate. All of these instruments worked as planned except the flow meter. The initial calibration figures given for the flow meter by the manufacturer were incorrect. Corrected numbers were obtained but were never entered into the logic of the flow meter. A flow measurement using orifices could have been taken to provide a calibration number for the meter, but this was not done during the short time that the plant operated using the well.

\section{Operation of the Dehydration Tunnel}

The product to be dried was loaded on screens (Fig. 13) that were then loaded on carts (Fig. 14). The carts were rolled into the dehydration tunnel, which would hold 7 carts. By staggering the times the carts were put into the tunnel and by inserting the carts at different ends of the tunnel, the tunnel could operate as a semi-continuous parallel-flow or counter-flow tunnel. Batch operations could also be done, but the products would dry at different rates, depending on the cart's order in the tunnel because of the increase of humidity in the air as it traversed the tunnel. Experience with drying indicated that there was very even drying on the carts, that is, products at different places on the cart did not dry at appreciably different rates.

Air-flow distribution measurements were done for the tunnel when the tunnel was fully loaded with empty carts. The measurements were taken at each of the seven cart locations at positions on the cart shown in Fig. 15. A summary of the measurements is shown in Table 1. From these results we can see that the air flow through the tunnel and carts is fairly uniform, a finding which was confirmed in the drying tests when it was found that the products on a cart dried evenly.

Table 2 presents a list of the products dried in the tests and Table 3 presents the results of some drying tests with bananas. In general, the tunnel was found to work satisfactorily. It required about 4 to 8 hours to dry a product like bananas. Different products were test-dried using both a boiler and the geothermal well as a source of steam. 


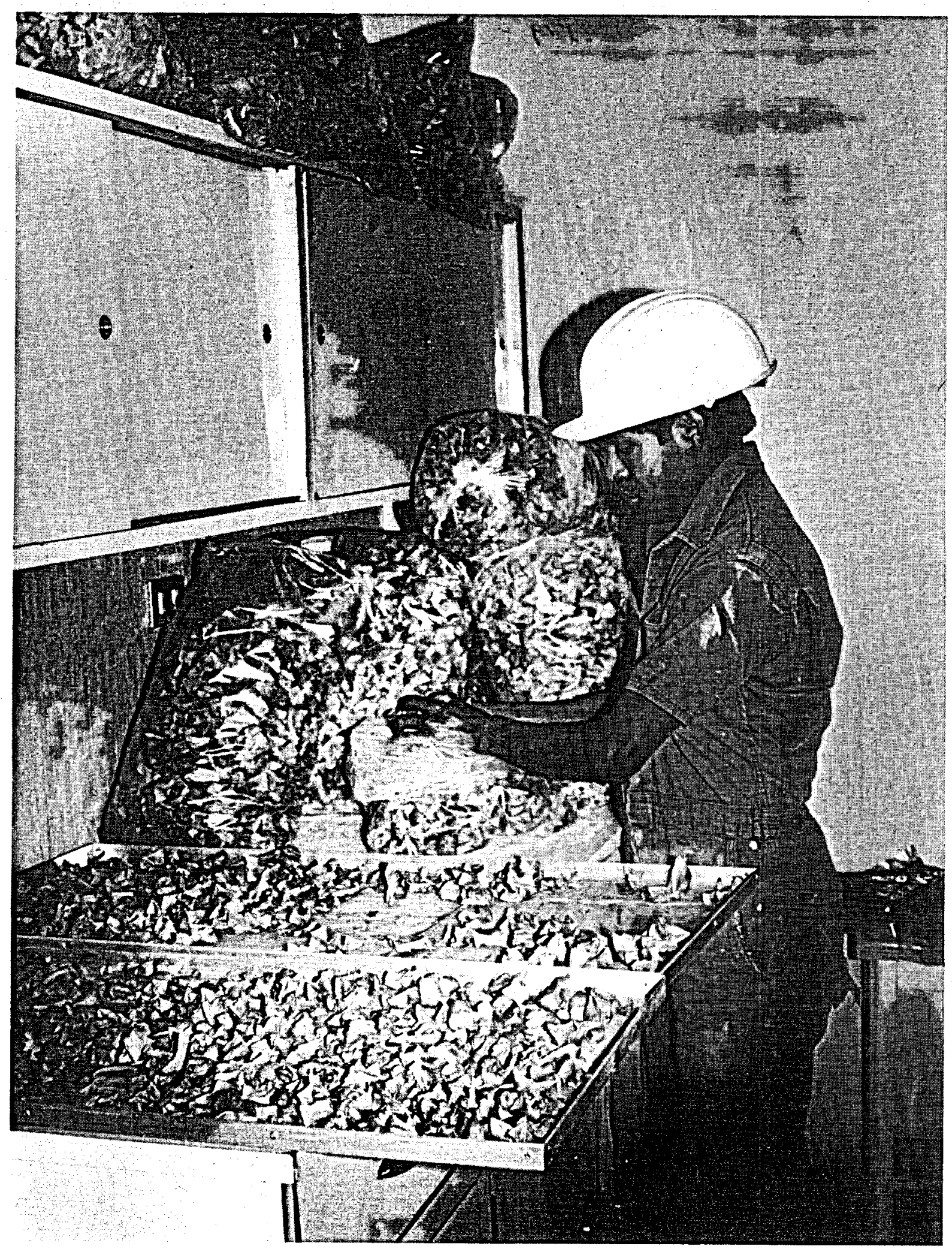

Figure 13. Removing produce from screens. 


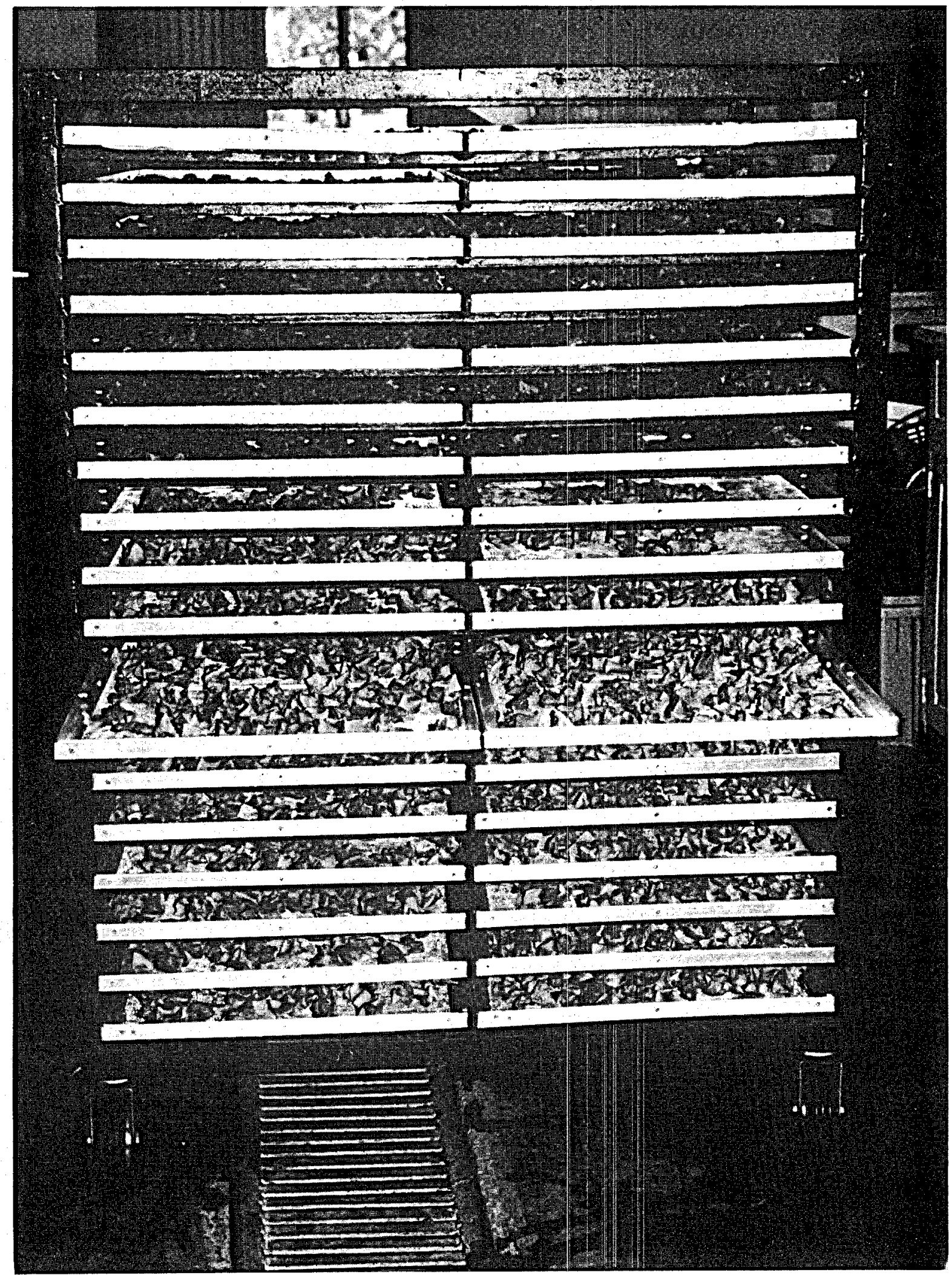

Figure 14. Carts for dehydrating produce. 


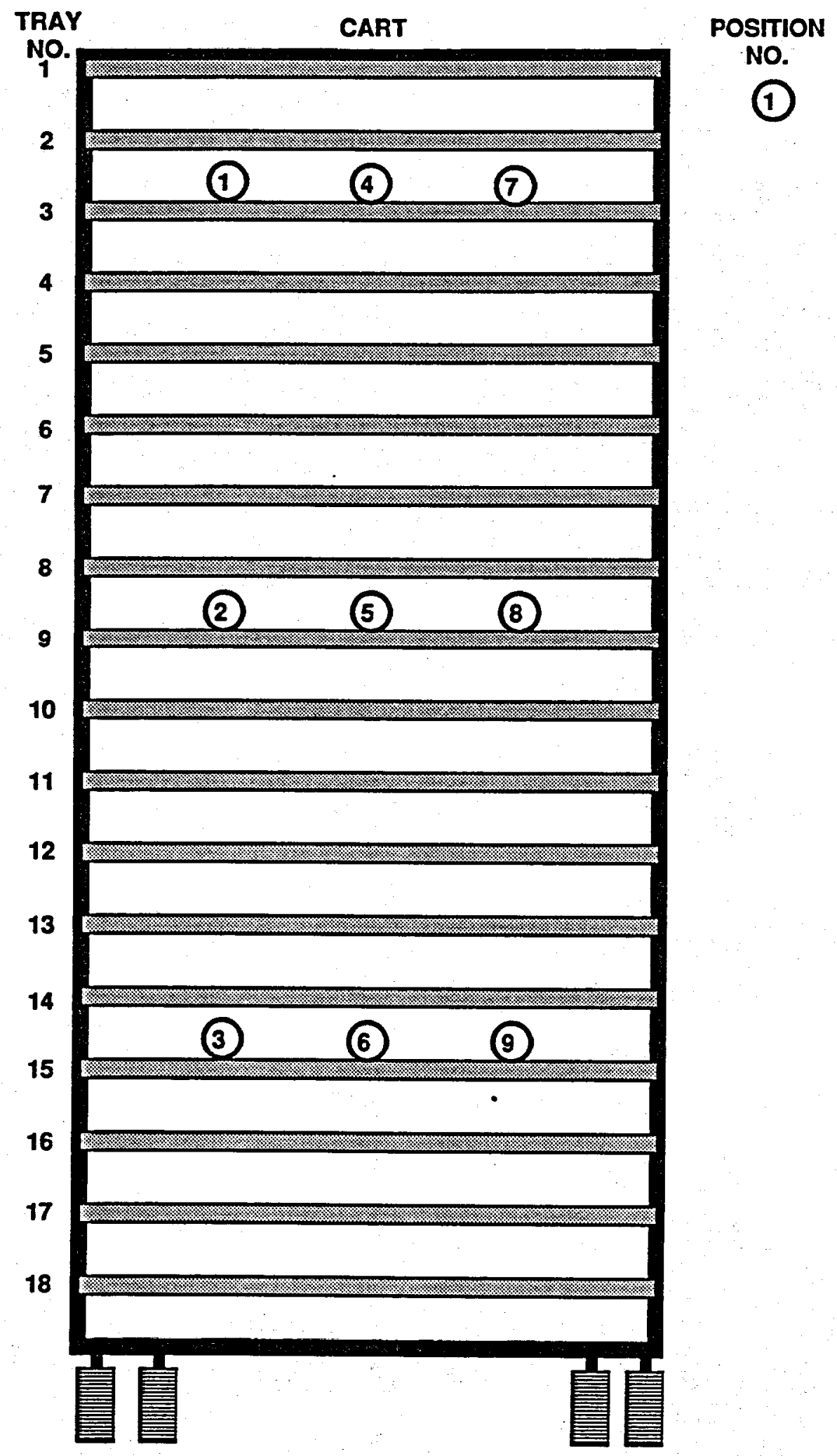

Figure 15. Location of air flow measurements on carts. 
TABLE 1

Air Flow Velocity Measurements for the Dehydration Tunnel

Average Air Velocity tt/min

Detector Location*

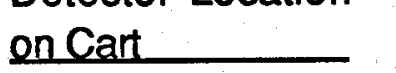

\begin{tabular}{lrrrrrrrr}
\hline & 1 & 2 & 3 & 4 & 5 & 6 & 7 \\
2 & 500 & 590 & 475 & 525 & 500 & 500 & 450 \\
3 & 450 & 550 & 490 & 425 & 475 & 475 & 425 \\
4 & 550 & 600 & 450 & 475 & 450 & 450 & 490 \\
5 & 490 & 550 & 525 & 540 & 525 & 550 & 525 \\
6 & 240 & 450 & 440 & 450 & 450 & 400 & 500 \\
7 & 610 & 475 & 425 & 475 & 525 & 425 & 525 \\
8 & 560 & 500 & 500 & 560 & 550 & 550 & 590 \\
9 & 540 & 475 & 440 & 475 & 450 & 475 & 475 \\
& 560 & 500 & 475 & $-\cdots$ & 550 & 525 & 450
\end{tabular}

"See Fig. 14.

** Position 1 is nearest to heat exchange end of tunnel.

TABLE 2

List of Products Test Dried at Zunil

Garlic (garlic powder)

Green bananas (banana flour)

Yellow tumeric (powdered tumeric)

Orange tumeric (powdered tumeric)

Ginger (powdered ginger)

Mango

Cashews

Green plantain (plantain flour)

Pineapple

Tomato

Parsley

Potatoes 


\section{TABLE 3}

Operation of Drying Tunnel (Ripe Bananas in Slices)

January 1990

\begin{tabular}{|c|c|c|c|c|c|c|c|c|}
\hline $\begin{array}{l}\text { Test } \\
\text { No. }\end{array}$ & Date & $\begin{array}{l}\text { Total } \\
\text { (lb) }\end{array}$ & $\begin{array}{c}\text { Waste } \\
\text { Final } \\
\text { Weight } \\
\text { (lb) }\end{array}$ & $\begin{array}{c}\text { Net } \\
\text { Weight } \\
\text { Input } \\
\text { (b) }\end{array}$ & $\begin{array}{c}\text { Net } \\
\text { Weight } \\
\text { Finished } \\
\text { (lb) }\end{array}$ & $\frac{\text { Waste }}{1}$ & $\begin{array}{l}\text { Water } \\
\frac{\text { Lost }}{\text { \% of Totall }}\end{array}$ & Prod. \\
\hline 1 & $11 / 06 / 89$ & 570.00 & 237.00 & 333.00 & 333.00 & 41.58 & 0.00 & 58.42 \\
\hline 2 & $11 / 07 / 89$ & 547.00 & 216.00 & 331.00 & 92.37 & 39.49 & 43.63 & 16.89 \\
\hline 3 & $11 / 08 / 89$ & 779.00 & 309.00 & 470.00 & 131.32 & 39.67 & 43.48 & 16.86 \\
\hline 4 & $11 / 09 / 89$ & 900.00 & 410.00 & 490.00 & 137.71 & 45.56 & 39.14 & 15.30 \\
\hline 5 & $11 / 10 / 89$ & 1665.00 & 778.00 & 39 & 39 & 46.73 & 37.33 & 15.94 \\
\hline 6 & $11 / 14 / 89$ & 1037.00 & 389.00 & 648.00 & 171.08 & 37.51 & 45.99 & 16.50 \\
\hline 7 & $11 / 15 / 89$ & 1315.00 & 530.00 & 785.00 & 211.64 & 40.30 & 43.30 & 16.09 \\
\hline 8 & $11 / 16 / 89$ & 656.00 & 230.00 & 426.00 & 96.16 & 35.06 & 50.28 & 14.66 \\
\hline 9 & $11 / 17 / 89$ & 614.00 & 234.00 & 380.00 & 91.00 & 38.11 & 47.07 & 14.82 \\
\hline 10 & $11 / 22 / 89$ & 870.00 & 313.00 & 557.00 & 139.58 & 35.98 & 47.98 & 16.04 \\
\hline 11 & $11 / 27 / 89$ & 926.00 & 364.00 & 562.00 & 178.00 & 39.31 & 41.47 & 19.22 \\
\hline 12 & $11 / 29 / 89$ & 997.00 & 406.00 & 591.00 & 160.41 & 40.72 & 43.19 & 16.09 \\
\hline 13 & $11 / 29 / 89$ & 1609.00 & 687.00 & 922.00 & 211.01 & 42.70 & 44.19 & 13.11 \\
\hline \multicolumn{2}{|c|}{ Totals \& Avg. } & 485.00 & 103.00 & 143.37 & 218.67 & 40.21 & 43.95 & 19.23 \\
\hline
\end{tabular}




\section{E. Operational Experience With the Instrumentation}

The original intent of the instrumentation design at the Zunil facility was to give the operators of the facility the ability to determine all the necessary parameters at the appropriate places in the facility. Thus, humidity meters, air-flow meters, and thermocouples that could be positioned at various places in the facility were provided. Pressure gauges, temperature gauges, and flow meters were placed in the hot water loop to provide parameters there. A secondary intent of the instrumentation design was to provide measurement with as little reliance as possible on calculations, thermocouple curves, etc., thus allowing personnel with minimal technical experience and training to determine values of the parameters. This design philosophy resulted in the installation in the facility of various electronic instruments, such as automatic thermocouple meters and digital, precalibrated flow meters. Because of lack of experience with the equipment and lack of local technical assistance and repair service from equipment manufacturers, considerable problems were encountered with the instrumentation. Through efforts of the plant manager and Los Alamos personnel, many of the problems were solved by providing alternative systems or by correcting deficiencies in installation. These solutions were found at the end of the time period when Los Alamos had responsibility for the facility and so we do not know whether these solutions have remained satisfactory for longer-term operation.

\section{E. Operational Experience With Other Portions of the Plant}

A minimum of amenities and equipment was designed for the rest of the facility. This was done because it was assumed that when a specific application for the plant was determined, the appropriate equipment for that application would be added. For the purpose of providing a technical demonstration of geothermal energy, the plan was to do most of the produce and food preparation by hand and to have a minimal amount of equipment for quality control of the food product and facility operation. Therefore, food preparation was time and labor consuming because little equipment existed and the facility was not able to perform the testing required for quality control. Because only short-term tests were done during this time and because no real "production" occurred at the facility during this testing period, these limitations were not a detriment to accomplishing the goal of the testing period, that is, to demonstrate that geothermal energy could be used for industrial purposes. 
When the facility is used on a more routine basis to test products or production, additional thought must be given to the addition of food processing equipment, laboratory equipment for quality control, and storage areas for incoming and processed products.

Some of the auxiliary areas, such as the lunchroom and showers, were not used as intended. These areas would be necessary in a production facility but have little utility for the type of operation done during this test period.

The operation of the chlorination system for the potable water was not feasible due to issues beyond the technical design. Since the agreement with the owner of the potable water source was that the water storage tank could only be filled at night, the chlorination system was never operated and so no experience with it can be reported.

Mixing geothermal-heated water with cold water to produce hot potable water of the desired temperature was found to work satisfactorily for providing water for the facility. The automatic valves were able to control the temperature of the hot water very well.

In general, if this facility is to be used as a production facility, some design changes and equipment additions are required and if a new production facility is built, changes to the design for the auxiliary areas would be necessary. 


\section{PRODUCT PROCESSING}

\section{A. Introduction}

When the plant was completed, Well Z-11 was closed because of testing in the Zunil well field. Nevertheless, several dehydration tests were done with various food products. The energy source used in these tests was a boiler that had been rented locally. The purpose of these tests was to generate interest in local farmers and cooperatives in using the facility, provide training for university students, investigate the possibility of creating products for market, and gain experience in the dehydration of various food products. The list of products tested is given in Table 2. Detailed information on drying times and curves is given (in Spanish) in the final report written by the plant manager, Oscar Maldonado, ${ }^{6}$ and is available from the International Program Office, ADET, Los Alamos National Laboratory.

\section{B. Dehydration Tests}

During the three months that the plant operated using the geothermal well as a source of steam, many test runs were done with the tunnel. In summary, there were 13 runs drying bananas, 5 runs drying apples, 6 runs drying pineapple, 4 runs drying potatoes, and 23 runs drying papaya. The results from one series of tests is given in Table 3. A total of $5675 \mathrm{~kg}$ of bananas, $730 \mathrm{~kg}$ of apples, $1780 \mathrm{~kg}$ of pineapple, $272 \mathrm{~kg}$ of potatoes, and $3240 \mathrm{~kg}$ of papaya were dehydrated during the time the plant was operational with geothermal steam.

\section{Results and Conclusions}

Despite the use of only the most basic food preparation and quality testing equipment, several successful tests of food dehydration were completed. The tests also created interest in the local farming populace in investigating dehydration as a method of processing their crops. 


\section{FACILITY COSTS}

\section{A. General}

The cost estimates are for replication of the Zunil facility and were obtained by using actual material and equipment costs for the present facility and estimates for INDE's labor and drilling costs. Site-specific engineering costs, US expediting costs, and project management costs for replication of the facility were estimated to be $25 \%$ of the total capital costs. The costs of the facility design done at Los Alamos were not included in these estimates because this was a first-of-a-kind facility and the design costs would not be encountered in building another facility. These facility cost estimates are presented in Table 4.

The costs have been divided into three parts: (1) well drilling costs, which include drilling, capping, and casing the well; (2) heat loop costs, which include the well Christmas tree, steam separator, silencer, heat exchanger, hot water loop piping, pumps, water-to-water heat exchanger, associated instrumentation, valves, and pipe supports; and (3) dehydration facility costs, which include the tunnel heat exchanger, fan, building, carts, trays, associated instrumentation, furniture, cabinets, and water supply. To provide a better comparison between the costs of the geothermal heat supply and a conventional boiler heat supply, the tunnel heat exchanger was included in the portion of the costs allocated to the dehydration facility because a similar piece of equipment is required even if a conventional boiler is used. The equipment costs are obtained from actual costs incurred or identified on this project up to January 1 , 1989 when the plant was operational.

\section{B. Facility Cost Estimate}

The well drilling costs were obtained for a well depth of $640 \mathrm{~m}$ and drilling costs of $\$ 300 / \mathrm{m}$. Obviously, these costs depend on the site and the size of the well. Well Z-11 is larger than is necessary for this facility. A smaller well could supply the required energy but may not be practical technically. Because the well is larger than needed, additional facilities could use the steam. Therefore, costs for the steam supply were analyzed in two ways. One way assumed that the well would be used exclusively for the food dehydration facility and the other assumed that the facility incurred the same percentage of the drilling costs as the percentage of the total energy of the well that the facility used. The latter case assumes that some other facility would accept the remainder of the drilling costs for its use of the energy. 


\section{TABLE 4}

Zunil Facility Capital Cost Estimates for Plant Replication

Well Drilling Cost Estimates 1

Well drilling and casing

192000

Engineering and project management (25\%)

48000

Subtotal well costs

$\$ 240000$

Heat Transfer Loop Costs

US-purchased materials

37676

Shipping

9810

Materials purchased in Guatemala

18771

Labor paid in Los Alamos

4530

Supervision paid in Los Alamos

7944

Expediting

11630

Estimated INDE labor

1765

Estimated INDE supervision

1736

Site-specific engineering, project management ${ }^{2}$

22265

Subtotal heat transport loop costs

$\$ 116127$

Dehydration Building Cost

US-purchased materials

12205

Shipping

2708

Materials purchased in Guatemala

32839

Labor paid in Los Alamos

3530

Supervision paid in Los Alamos

6944

Expediting paid in Los Alamos

11630

INDE labor

7000

INDE supervision

7000

Site-specific engineering, project management ${ }^{2}$

21550

Subtotal dehydration bldg.

$\$ 104856$

Project costs assuming that $100 \%$ of well costs are attributable to project. $\$ 460983$

Project costs assuming that $20 \%$ of well costs ${ }^{3}$ are attributable to project. $\$ 268983$

1Assumes: Drilling $\operatorname{cost}^{3} \$ 300 / \mathrm{m}$.

Casing costs included in above.

Zunil well is $640 \mathrm{~m}$ deep.

$225 \%$ of total cost.

${ }^{3}$ The dehydration facility required $20 \%$ of the energy (before steam separation) that was being produced by the well. The plant actually used only $8 \%$ of the total energy, but the additional $12 \%$ was required to provide steam separation at a reasonable temperature. 
The total cost of supplies and equipment purchased in Guatemala and labor and supervisory costs paid by Los Alamos are known accurately for the project. However, an estimate was made of the division of these costs between the heat loop and the dehydration facility. Thus, while costs for the overall project are accurate for these items, the cost of the items for the two different components will have some uncertainty associated with them. INDE labor costs were estimated by assuming that worker wages were the same as those being paid by Los Alamos for local labor and by estimating the amount of time spent by INDE workers on the facility compared to the time spent by the workers paid by Los Alamos. The expeditor costs listed are actual costs paid by Los Alamos. The services performed included obtaining bids on and purchasing equipment and material in Guatemala.

The heat loop costs were obtained by adding up the cost of US-purchased heat loop equipment, shipping, supplies, and equipment purchases in Guatemala; expediting, labor, and supervisory costs paid by Los Alamos; estimates of INDE labor and supervisory costs; and $25 \%$ of the capital cost for site-specific design and project management. It was assumed that INDE employees spent the same amount of manhours working on the heat loop as did Los Alamos employees. Los Alamos paid for such a large portion of the heat loop labor primarily because INDE was on strike much of the time that heat loop construction was under way.

The dehydration facility cost was obtained by adding up the costs for USpurchased materials, shipping, Los Alamos expediting, labor, and supervisory costs; estimate of INDE labor and supervisory costs; and 25\% of the capital costs for sitespecific design and project management. It was assumed that INDE spent twice the man-hours in constructing the building and water supply than did Los Alamos paid labor. This initial construction was done by INDE, but most of the finish work and equipment installation was done by Los Alamos paid labor.

\section{Cost of Conventional Heat Supply (Boiler)}

To compare the costs of the geothermal steam supply with that of a conventional heat supply system, capital and operating costs were obtained for a 30-hp boiler that could supply the steam requirements for the facility: The capital costs presented in Table 5 are for the boiler that was purchased for the facility when 
Well Z-11 was closed. The costs include the boiler, fuel storage, and installation. It is assumed that the boiler will take the place of the geothermal well and the heat loop in the Zunil facility. The costs for the dehydration facility are assumed to be the same whether a boiler or geothermal steam is used as the energy supply.

\section{Operating Costs}

Operating costs for the geothermal steam supply and the boiler were estimated for the Zunil facility. Specific assumptions used in the estimate are given in Table 6. Operating costs were only obtained for the energy supply of the dehydration facility and not for food processing because these costs are highly dependent on the type of processing being done. (And again, these costs should be independent of the source of the energy for the plant as long as the energy supply can produce the required conditions in the facility.)

\section{E. Results}

Results of the analysis are presented in Table 7. These results show that the cost of energy from geothermal sources over the 15-year lifetime of the plant is similar to that of a conventional plant when the full cost of the well is included in the geothermal energy costs. However, the well can be used more efficiently by having other users connected to it or by constructing a larger facility. If the facility only needs to pay the percentage of well costs for the percentage of the energy that it uses, then geothermal energy is considerably less expensive that the conventional system of a diesel-fueled boiler. If waste heat from an electrical production facility is used as the energy supply, the well costs would be zero, thus making geothermal energy considerably cheaper than diesel. 
TABLE 5

CONVENTIONAL BOILER CAPITAL COST

30-hp Boiler (installed)

13000

Fuel Tank

1600

Site Preparation and Engineering (25\%)

3650

Total Boiler Capital Costs

$\$ 18250$

\section{TABLE 6}

Annual Operating And Maintenance Cost Estimates

FOR GEOTHERMAL AND BOILER SYSTEMSa

Geothermal Operating and Maintenance Costs

Annual operating costs

2000

Heat loop maintenance ( $10 \%$ of capital)

11130

Well maintenance (2.5\% of capital)

6000

Annual Total

Boiler Operating and Maintenance Costs

Annual operating costs

2000

Maintenance cost (5\% of capital)

1000

Fuel costb

48450

Annual Total

$\$ 51450$

aAssume 30-hp Boiler

bAssumptions: 20 hours/week operation

50 weeks/year

9.5 gallons per hour diesel consumption

$\$ 0.85 /$ fuel for diesel (delivered) 


\section{TABLE 7}

Comparison of Annual Costs for Geothermal and Boiler Energy Supply System

Geothermal System

Geothermal Energy Supply Capital Cost

$100 \%$ of well costs $a$

356127

$20 \%$ of well costs $b$

Annual Capital CostsC

$100 \%$ of well costs

32030

$20 \%$ of well costs

Operation and Maintenance Costs

Total Annual Cost

$100 \%$ of well costs

51160

$20 \%$ of well costs

33892

Boiler System

Boiler Capital Cost

18250

Annual Boiler Costc

1641

O\&M \& Fuel Costs

51450

Total Annual Cost

$\$ 53091$

aAssumes a well the same size as Well $Z-11$ was drilled specifically for the application.

bAssumes that other applications can use the excess energy and will assume the appropriate percentages of well costs.

CAssumes $4 \%$ real (actual rate-inflation) interest rate and 15 -year lifetime of system. 


\section{SUMMARY AND RECOMMENDATIONS}

\section{A. Summary}

The geothermal dehydration facility at Zunil has successfully demonstrated the use of geothermal energy for industrial purposes, specifically for the dehydration of food products. Although the facility did not operate for a long time using geothermal steam as an energy source, we demonstrated that it operated satisfactorily on geothermal power.

As with most first-of-a-kind plants, some modifications of the original design are needed or would be helpful. The corrosion in the hot water loop caused problems with the designed control system. Modifications and/or simplification of the control system could help alleviate this problem. Other solutions might include more careful control of the corrosion in the loop through chemical cleaning of the pipe, alternative piping materials, water chemistry controls, or designing the system so that a rust inhibitor can be used in the hot water loop. Other problems encountered in the construction were due to the location of the well in the bottom of a canyon, complicating construction of the hot water loop.

Because of budget and time limitations, the facility was never completely tested for all modes of operation and for the numerous combinations of the controllable factors such as tunnel air flow, heat loop flow rate, and steam flow. However, the utility of large amounts of these data is questionable. It was demonstrated that the facility could successfully dehydrate fruits and vegetables with enough quality control to produce an acceptable product.

The operation of the facility generated considerable interest from local farmers, cooperatives, and students, and numerous products were tested for these people and organizations. The tests performed indicated (1) new methods of preserving crops, (2) the possibility of utilizing previously discarded produce, and (3) possible new markets for the local produce. The continuing operation of the plant by MOSCAMED increased the number of products tested and provided additional insights into new products and processes. Although the project had problems, on the whole it would have to be considered a successful technical demonstration of the use of geothermal energy for industrial processes. 


\section{B. Recommendations}

We recommend that the facility continue to be used. Ownership of the facility has been transferred to INDE, and INDE should continue to make it available to interested parties. Even operating with a boiler, the facility should be able to produce products that will have a market value.

We also recommend that the facility use the waste heat from the power plant that is planned for Zunil. The waste heat from a steam separator for Well 3 could supply more than enough energy to operate the facility. If the Zunil facility is connected to the waste heat generated by the power plant, it will probably demonstrate the cheapest source of geothermal energy for industrial processes because it will be using a resource that normally would have been wasted.

There are many other geothermal areas in Guatemala and Central America and when these areas are investigated, industrial uses of geothermal energy should always be considered. For example, test wells should be completed so that they can be used as energy sources for industrial processes. If a well does not produce high enough temperatures for electrical production, it should be considered for providing industrial energy. Also, fields that are not hot enough for electrical production should be considered as possible sources of industrial energy. And if geothermal power plants are constructed, the waste heat should be made available for industrial purposes. Industrial or direct heat applications of geothermal energy are excellent ways to maximize use of the geothermal resources available to Guatemala.

\section{Other Industrial Applications of Geothermal Energy}

Almost any industrial process that utilizes unpressurized wet steam, hot water, or temperatures at or below the boiling point of water could make use of the geothermal steam at Zunil, either from Well Z-11 or from the waste heat of a geothermal electrical plant. Additional industrial-scale food processing and drying is an obvious extension for direct heat applications in Zunil. Fruit juice concentration is another food processing application that might be practical. Other possible applications include distillation processes such as alcohol production and, at lower temperatures, applications such as concrete block curing, fish pond heating, and 
greenhouse heating for tree seedlings. Cloth dying and processing are being tested in the Hawaii geothermal test program and could be of great interest in the Zunil area. Tanneries could also use geothermal energy for their processes.

This is only a very short list of possible applications. Additional applications might be suggested, especially by people living in the area and familiar with the resources and activities around Zunil. We hope that INDE and the government of Guatemala will make geothermal resources available to industrial users, either in the form of unwanted wells or as waste heat from the power plants, allowing them to use this inexpensive and abundant energy resource. 


\section{REFERENCES}

1. Furumoto, A. S., Cloth Dyeing by Geothermal Steam, (Community Geothermal Technology Program, Hawaii Energy Extension Service, Hilo, HI, December 1987).

2. Papaya Products of Hawaii, Fruit Drying with Geothermal Energy, (Community Geothermal Technology Program, Hawaii Energy Extension Service, Hilo, HI, March 1988).

3. Nichols, K. E, "Modular Well Head Power Plants," in Proceedings of the Topical Meeting on Small-Scale Geothermal Power Plants and Power Plant Projects," Reno, Nevada, February 1986, 59-65.

4. Biak, S. "Preliminary Studies of Culture of Commercially Important Tropical Fishes Utilizing Nevada Geothermal Aquifer to Simulate Tropical Conditions," in Building the Future, Geothermal Resource Council 1987 Annual Meeting, Vol. 11, Sparks, Nevada, October 1987, pp 3-5.

5. Altseimer, J. H. and F. J. Edeskuty, "A Survey of Geothermal Process Heat Applications in Guatemala," Los Alamos National Laboratory report LA-11326-MS (August 1988).

6. Maldonado, O., "Planta Zunil Reporte Final," Consultecnia, Guatemala City, Guatemala, 1990. 


\section{APPENDIX}


TABLE A-1

Water \& Steam Mass Balance Flow for Well Z-11 and the Dehydration Facilitya

November 1989

\begin{tabular}{|c|c|c|c|c|c|c|c|c|c|c|c|}
\hline & \multicolumn{2}{|c|}{ Nater Flow } & \multirow{2}{*}{$\begin{array}{l}\text { Separator } \\
\text { Condensate } \\
\text { (bmh }\end{array}$} & \multicolumn{2}{|c|}{ Mixed Fluid } & \multicolumn{2}{|c|}{ Steam Flow to } & \multicolumn{2}{|c|}{ Steam Water } & \multirow{2}{*}{$\begin{array}{l}\text { Total } \\
\text { Fluid } \\
\text { Production } \\
\text { (lb/hl }\end{array}$} & \multirow{2}{*}{$\begin{array}{l}\text { Percent } \\
\text { Steam } \\
\text { Utillization }\end{array}$} \\
\hline & $\begin{array}{l}\text { Silencer } \\
(\mathrm{b} / \mathrm{h})\end{array}$ & $\begin{array}{c}\text { Separator } \\
(\mathrm{lb} / \mathrm{h})\end{array}$ & & $\begin{array}{l}\text { Silencer } \\
\text { (lbuh) }\end{array}$ & $\begin{array}{c}\text { Separator } \\
\text { (lbah) }\end{array}$ & $\begin{array}{c}\text { Silencer } \\
(1 b / h)\end{array}$ & $\begin{array}{l}\text { Separator } \\
\text { (lb/h) }\end{array}$ & $\begin{array}{c}\text { Production } \\
(|b| b \mid)\end{array}$ & $\begin{array}{l}\text { Production } \\
\text { (b/b) }\end{array}$ & & \\
\hline $7 / 89$ & 4380.00 & 0.00 & 357.80 & 6375.55 & 0.00 & 1995.55 & 0.00 & 1995.55 & 4380.00 & 375.55 & 17.93 \\
\hline 18/89 & 4118.85 & 0.00 & 7.20 & 5.41 & 0.00 & .56 & 0.00 & 097650 & 4118.85 & 5995.41 & 3.17 \\
\hline $11 / 9 / 89$ & 3967.80 & 0.00 & 285.70 & 75.55 & 0.00 & 307.75 & 0. & 1 & 396 & 775.55 & 5.80 \\
\hline 0/89 & 3459.20 & 0.00 & 271.50 & 5035.23 & 0.00 & 1576.03 & 0.00 & 1576.03 & 3459.20 & 5035.23 & 17.23 \\
\hline $4 / 89$ & 3382.90 & 0.00 & 418.40 & 4924.16 & 0.00 & 1541.26 & 0.00 & 154 & 3382.90 & 924.16 & 27.15 \\
\hline $5 / 89$ & 36.9 & 778.20 & 39 & 5 & 1 & 1565.87 & 3 & 88 & 10 & 094. & 4.14 \\
\hline /16/89 & 3229.1 & 8 & 244.65 & 9 & 1 & 9 & 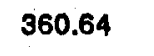 & & 5 & 5954. & 13.36 \\
\hline $11 / 17 / 89$ & 3091.00 & 866.70 & 236.70 & 4499.27 & 1216.42 & 408.27 & 349. & 1 & 0 & 5715.69 & 13.46 \\
\hline $20 / 89$ & 3169.40 & 883.35 & 231.00 & 4613.39 & 1239.79 & 1443.99 & 356.44 & 1800.43 & 4052.75 & 853.18 & 12.83 \\
\hline $2 / 89$ & 3099.8 & 970 & 300 & 12.08 & 1248.70 & 1412.28 & 359.00 & 1771.28 & 3989.50 & 5760.78 & 12.59 \\
\hline $3 / 89$ & 30. & 200 & & 7 & 1265.96 & 1380.57 & 363.96 & 174 & 3932.20 & 676.74 & 11.06 \\
\hline $27 / 89$ & 152.7 & 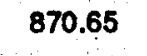 & 222.30 & 6 & 1 & 11 & 31 & 17 & 4023.40 & 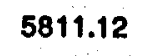 & 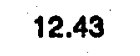 \\
\hline 28/89 & 3109.30 & 863.60 & 290.00 & 5.91 & 1212.07 & 6.61 & 348.47 & 176 & 20 & 737.98 & 16.43 \\
\hline 29/89 & 3197.00 & 867.90 & 254.40 & 4653.57 & 1218.11 & 1456.57 & 350.21 & 1806.77 & 4064.90 & 5871.67 & 14.09 \\
\hline 9 & 8 & - & 182.90 & 73.51 & 84.35 & 1431.51 & . 369,25 & 1800.76 & 4057.10 & 85. & 10.16 \\
\hline verag & 97.75 & 873.10 & 274.17 & 4945.77 & 1225.40 & 1548.03 & 352.30 & 1782.89 & 3979.81 & 5762.70 & 15.46 \\
\hline
\end{tabular}

aOscar Maldonado, "Planta Zunil Reporte Finale," Consultecnla, Guatemala City, Guatemala, 1990. 
TABLE A-2

Water \& Steam Mass Balance Flow for Well Z-11 and the Dehydration Facilitya

December 1989

\begin{tabular}{|c|c|c|c|c|c|c|c|c|c|c|c|}
\hline 20 & $\begin{array}{l}\text { Wate } \\
\text { Silencer } \\
(\mathrm{lb} / \mathrm{h})\end{array}$ & $\begin{array}{l}\text { Flow to } \\
\text { Separator } \\
(\mathrm{b} / \mathrm{h})\end{array}$ & $\begin{array}{l}\text { Separator } \\
\text { Condensate } \\
\text { (lb hl }\end{array}$ & $\begin{array}{l}\text { Mixed } \\
\text { Silencer } \\
\text { (llbh). }\end{array}$ & $\begin{array}{l}\text { d Fluid to } \\
\text { Separator } \\
(\text { blol }\end{array}$ & $\begin{array}{c}\text { Steam } \\
\text { Silencer } \\
\text { (lbah) }\end{array}$ & $\begin{array}{l}\text { Flow to } \\
\text { Separator } \\
\text { (lbah) }\end{array}$ & $\begin{array}{r}\text { Steam } \\
\text { Production } \\
\text { (boh) }\end{array}$ & $\begin{array}{l}\text { Water } \\
\text { Production } \\
\text { (bn }\end{array}$ & $\begin{array}{l}\text { Total } \\
\text { Fluid } \\
\text { Production } \\
\text { (lbbl) }\end{array}$ & $\begin{array}{l}\text { Percent } \\
\text { Steam } \\
\text { Utilization }\end{array}$ \\
\hline $1 / 189$ & 3151.60 & .90 & 203.40 & 4587.48 & 1267 & 15.88 & 364.33 & 1 & 40 & & 1.30 \\
\hline $2 / 89$ & 3228.70 & 881.00 & 4.90 & 4699.71 & 1236.49 & 1 & 355.49 & 0 & 0 & 0 & 9.03 \\
\hline 6/89 & 3435.20 & -1 & 5.00 & 5000.29 & 1000.70 & 1565.09 & 287.70 & 1852.79 & 4148.20 & 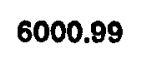 & 7.83 \\
\hline$/ 7 / 89$ & 2893.86 & 48.30 & 30.93 & 4212.31 & 1190.60 & 1318.45 & 342.30 & 1660.75 & 3742.16 & 402.91 & 13.91 \\
\hline $1 / 89$ & 3358.70 & 912.20 & 1.90 & 88.94 & 1280.28 & 530.24 & 368.08 & 1898.32 & 4270.90 & 169.22 & 13.27 \\
\hline$/ 10 / 89$ & 3367.40 & 859.40 & 267.60 & 4901.60 & 1206.18 & 1534.20 & 346.78 & 1880.98 & 4226.80 & 6107.78 & 14.23 \\
\hline $12 / 11 / 89$ & 3370.00 & 880.58 & 237.70 & 4905.39 & 1235.90 & 1535.49 & 355.32 & 1890.71 & 4250.58 & 1.29 & 12.57 \\
\hline $2 / 13 / 89$ & 3469.90 & 901.75 & 08.20 & 5050.80 & 1265.61 & 80.90 & 363.86 & 1944.76 & 4371.65 & 6316.41 & 10.71 \\
\hline 2/14/89 & 3389.80 & 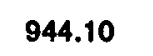 & 170.00 & 4934.21 & 1325.05 & 1544.41 & 380.95 & $15<0.00$ & 4333.90 & 0203.20 & 1.10 \\
\hline 189 & 3 & 723.30 & 150.70 & 9 & 1 & 9 & 2 & & 405 & 15 & 3.32 \\
\hline /89 & 3361. & 7 & 0 & 2 & 1007.30 & .42 & 289.60 & 182 & 407 & 2 & 8.67 \\
\hline 2/18/89 & 3263.50 & 722.1 & 150.40 & 4750.36 & 1013.47 & 1486.86 & 28 & 24 & 0 & 34 & 8.46 \\
\hline 2/28/89 & 3358.60 & 8.00 & 158.80 & 4888.79 & 1063 & 1530.19 & 305.86 & 1836.05 & 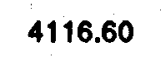 & 200 & 8.65 \\
\hline 9 & 3 & 793.90 & . & 5 & . & 660.95 & 320.3 & 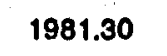 & 76 & . & 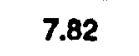 \\
\hline /89 & 3414.80 & 20.00 & $101 .<0$ & 4970.60 & 1164.77 & 1555.80 & 334.87 & 1890.67 & 4244.70 & 135.37 & 8.00 \\
\hline 189 & 3519.60 & 281.90 & 151.50 & 5123.14 & 1097.40 & 1603.54 & 5.50 & 1919.05 & 4301.50 & 6220.55 & 7.89 \\
\hline verage & 3347.65 & 823.13 & 183.36 & 4372.85 & 1155.27 & 1525.20 & 332.14 & 1857.34 & 4170.77 & 6028.12 & 9.90 \\
\hline
\end{tabular}

aOscar Maldonado, "Planta Zunil Reporte Finale," Consultecnia, Guatemala City, Guatemala, 1990. 
TABLE A-3

Energy Balance for Well Z-11 and the Dehydration Facilitya

November 1989

\begin{tabular}{|c|c|c|c|c|c|c|c|c|c|}
\hline ato & $\begin{array}{l}\text { Total } \\
\text { Steam } \\
\text { Production } \\
\text { (lbh) }\end{array}$ & $\begin{array}{l}\text { Total } \\
\text { Water } \\
\text { Production } \\
\text { (lb/h) }\end{array}$ & $\begin{array}{l}\text { Total } \\
\text { Mixed } \\
\text { Flow } \\
\text { (lb/h) }\end{array}$ & $\begin{array}{l}\text { Steam } \\
\text { Energy } \\
\text { (Btuh) }\end{array}$ & $\begin{array}{l}\text { Water } \\
\text { Energy } \\
\text { (Btum) }\end{array}$ & $\begin{array}{l}\text { Total } \\
\text { Energy } \\
\text { (Btum) }\end{array}$ & $\begin{array}{l}\text { Condensate } \\
\text { Flow } \\
\text { (lbm) }\end{array}$ & $\begin{array}{l}\text { Condensate } \\
\text { Energy } \\
\text { (Btum) }\end{array}$ & $\begin{array}{l}\text { Energy } \\
\text { Consumed }\end{array}$ \\
\hline $11 / 7 / 89$ & 1995.55 & 4380.00 & 6375.55 & 2314838.00 & 621960.00 & 2936798.Q0 & 357.80 & 415048.00 & 14.13 \\
\hline $11 / 8 / 89$ & 1876.56 & 4118.85 & 5995.41 & 2176809.60 & 584876.70 & 2761686.30 & 247.20 & 286752.00 & 10.38 \\
\hline $11 / 9 / 89$ & 1807.75 & 3967.80 & 5775.55 & 2096990.00 & 563427.60 & 2660417.60 & 285.70 & 331412.00 & 12.46 \\
\hline $11 / 10 / 89$ & 1576.03 & 3459.20 & 5035.23 & 1828194.80 & 491206.40 & 2319401.20 & 272.50 & 316100.00 & 13.63 \\
\hline $11 / 14 / 89$ & 1541.26 & 3382.90 & 4924.16 & 1787861.60 & 480371.80 & 2268233.40 & 418.40 & 485344.00 & 21.40 \\
\hline $11 / 15 / 89$ & 1879.88 & 4215.10 & 6094.98 & 2180660.80 & 598544.20 & 2779205.00 & 453.89 & 526512.40 & 18.94 \\
\hline $11 / 16 / 89$ & 1831.83 & 4122.85 & 5954.68 & 2124922.80 & 585444.70 & 2710367.50 & 244.65 & 283794.00 & 10.47 \\
\hline $11 / 17 / 89$ & 1757.99 & 3957.70 & 5715.69 & 2039268.40 & 561993.40 & 2601261.80 & 236.70 & 274572.00 & 10.56 \\
\hline $11 / 20 / 89$ & 1800.43 & 4052.75 & 5853.18 & 2088498.80 & 575490.50 & 2663989.30 & 231.00 & 267960.00 & 10.06 \\
\hline 11/22/89 & 1771.20 & $\mathbf{3 9 8 9 . 5 0}$ & 5760.78 & 2054684.80 & 566509.00 & 2621193.80 & 223.00 & 258680.00 & 9.87 \\
\hline $11 / 23 / 89$ & 1744.54 & 3932.30 & 5676.84 & 2023666.40 & 558386.60 & 2582053.00 & 193.00 & 223880.00 & 8.67 \\
\hline $11 / 27 / 89$ & 1787.72 & 4023.40 & 5811.12 & 2073755.20 & 571322.80 & 2645078.00 & 222.30 & 257868.00 & 9.75 \\
\hline $11 / 28 / 89$ & 1765.08 & 3972.90 & 5737.98 & 2047492.80 & 564151.80 & 2611644.60 & 290.00 & 336400.00 & 12.88 \\
\hline $11 / 29 / 89$ & 1806.77 & 4064.90 & 5871.67 & 2095853.20 & 577215.80 & 2673069.00 & 254.50 & 295220.00 & 11.04 \\
\hline 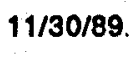 & 18 & 4 & 5858.52 & 188881.60 & 576201.92 & 2665083.52 & 18 & 64.00 & 7.86 \\
\hline rage & 1782.90 & 3979.86 & 5762.76 & 2068158.59 & 565140.21 & 2633298.80 & 274.24 & 318113.76 & 12.15 \\
\hline
\end{tabular}

aOscar Maldonado, "Planta Zunil Reporte Finale," Consultecnia, Guatemala City, Guatemala, 1990. 
TABLE A-4

Energy Balance for Well Z-1 and the Dehydration Facilitya

December 1989

\begin{tabular}{|c|c|c|c|c|c|c|c|c|c|}
\hline Date & $\begin{array}{l}\text { Total } \\
\text { Steam } \\
\text { Production } \\
\text { (lbh) }\end{array}$ & $\begin{array}{l}\text { Total } \\
\text { Water } \\
\text { Production } \\
\text { (lbah) }\end{array}$ & $\begin{array}{l}\text { Total } \\
\text { Mixed } \\
\text { Flow } \\
\text { (lbm) } \\
\end{array}$ & $\begin{array}{l}\text { Stoam } \\
\text { Energy } \\
\text { (Buph) }\end{array}$ & $\begin{array}{l}\text { Water } \\
\text { Energy } \\
\text { (Btuph) }\end{array}$ & $\begin{array}{l}\text { Total } \\
\text { Energy } \\
\text { (Bhum) }\end{array}$ & $\begin{array}{l}\text { Condensate } \\
\text { Flow } \\
\text { (lb/h) }\end{array}$ & $\begin{array}{l}\text { Condensate } \\
\text { Energy } \\
\text { (Bruh) }\end{array}$ & $\begin{array}{l}\text { Energy } \\
\text { Consumed }\end{array}$ \\
\hline $12 / 1 / 89$ & 1800.21 & 4054.50 & 5854.71 & 2088243.60 & 575739.00 & 2663982.60 & 203.40 & 235944.00 & 8.86 \\
\hline $12 / 2 / 89$ & 1826.50 & 4109.70 & 5936.20 & 2118740.00 & 583577.40 & 2702317.40 & 164.90 & 191284.00 & 7.08 \\
\hline $12 / 6 / 89$ & 1852.79 & 4148.20 & 6000.99 & 2149236.40 & 589044.40 & 2738280.80 & 145.00 & 168200.00 & 6.14 \\
\hline $12 / 7 / 89$ & 1660.75 & 3742.16 & 5402.91 & 1926470.00 & 531386.72 & 2457856.72 & 230.93 & 267878.80 & 10.90 \\
\hline $12 / 8 / 89$ & 1898.32 & 4270.90 & 6169.22 & 2202051.20 & 606467.80 & 2808519.00 & 251.90 & 292204.00 & 10.40 \\
\hline $12 / 11 / 89$ & 1880.88 & 4226.80 & 6107.78 & 2181936.80 & 600205.60 & 2782142.40 & 267.60 & 310416.00 & 11.16 \\
\hline $12 / 12 / 89$ & 1890.71 & 4250.58 & 6141.29 & 2193223.60 & 603582.36 & 2796805.96 & 237.70 & 275732.00 & 9.86 \\
\hline 12/13/89 & 1944.76 & 4371.65 & 6316.41 & 2255921.60 & 620774.30 & 2876695.90 & 208.20 & 241512.00 & 8.40 \\
\hline $12 / 14 / 89$ & 1925.36 & 4333.90 & 6259.26 & 2233417.60 & 615413.80 & 2848831.40 & 148.80 & 172608.00 & 6.06 \\
\hline $12 / 15 / 89$ & 1810.75 & 4057.10 & 5867.85 & 2100470.00 & 576108.20 & 2676578.20 & 150.70 & 174812.00 & 6.53 \\
\hline $12 / 16 / 89$ & 1821.02 & 4079.00 & 5900.02 & 2112383.20 & 579218.00 & 2691601.20 & 157.80 & 183048.00 & 6.80 \\
\hline 12/18/89 & 1778.24 & 3985.60 & 5763.84 & 2062758.40 & 565955.20 & 2628713.60 & 150.40 & 174464.00 & 6.64 \\
\hline 12/28/89 & 1836.05 & 4116.60 & 5952.65 & 2129818.00 & 584557.20 & 2714375.20 & 158.80 & 184208.00 & 6.79 \\
\hline 12/29/89 & 1981.20 & 4439.50 & 6420.70 & 2298192.00 & 630409.00 & 2928601.00 & 155.00 & 179800.00 & 6.14 \\
\hline 12/30/89 & 1890.67 & 4244.70 & 6135.37 & 2193177.20 & 602747.40 & 279592 & 151.20 & 175392.00 & 6.27 \\
\hline 12 & and & 4301.50 & 6220.55 & 226098.00 & 610813,00 & 2836911.00 & 151.50 & 175740.00 & 6.19 \\
\hline erage & 1857.34 & 4170.77 & 6028.11 & 2154508.60 & 592249.96 & 2746758.56 & 183.36 & 212702.68 & 7.76 \\
\hline
\end{tabular}

aOscar Maldonado, "Planta Zunil Reporte Finale," Consultecnia, Guatemala City, Guatemala, 1990. 